\title{
Freshwater gastropods diversity hotspots: three new species from the Uruguay River (South America)
}

Diego E Gutiérrez Gregoric, Micaela de Lucía

Background. The Atlantic Forest is globally one of the priority ecoregions for biodiversity conservation. In Argentina, it is represented by the Paranense Forest, which covers a vast area of Misiones Province between the Paraná and Uruguay rivers. The Uruguay River is a global hotspot of freshwater gastropod diversity, here mainly represented by Tateidae (genus Potamolithus) and to a lesser extent Chilinidae. The family Chilinidae (Gastropoda, Hygrophila) includes 21 species currently recorded in Argentina, and three species in the Uruguay River. The species of Chilinidae occur in quite different types of habitats, but generally in clean oxygenated water recording variable temperature ranges. Highly oxygenated freshwater environments (waterfalls and rapids) are the most vulnerable continental environments. We provide here novel information on three new species of Chilinidae from environments containing waterfalls and rapids in the Uruguay River malacological province of Argentina. Materials \& Methods. The specimens were collected in 2010. We analyzed shell, radula, and nervous and reproductive systems, and determined the molecular genetics. The genetic distance was calculated for two mitochondrial markers (cytochrome $c$ oxidase subunit I -COI- and cytochrome b -Cyt b-) for these three new species and the species recorded from the Misionerean, Uruguay River and Lower Paraná-Río de la Plata malacological provinces. In addition the COI data were analyzed phylogenetically by the neighbor-joining and Bayesian inference techniques. Results. The species described here are different in terms of shell, radula and nervous and reproductive systems, mostly based on the sculpture of the penis sheath. Phylogenetic analyses grouped the three new species with those present in the Lower Paraná-Río de La Plata and Uruguay River malacological provinces. Discussion. Phylogenetic analyses confirm the separation between the Uruguay River and the Misionerean malacological provinces in northeast Argentina. These new endemic species from the Uruguay River add further support to the suggestion that this river is a diversity hotspot of freshwater gastropods (with 54 species present in this basin, 15 of them endemic). These endemic species from environments with rapids and waterfalls should be taken into account by government agencies before the construction of dams that modify those ecologic niches in the Uruguay River. 
1 Freshwater gastropod diversity hotspots: three new species from the Uruguay River (South 2 America)

3

4 Diego Eduardo Gutiérrez Gregoric ${ }^{1,2 *}$, Micaela de Lucía ${ }^{1}$

5

$6 \quad$ ㄹivisión Zoología Invertebrados, Museo de La Plata, Facultad de Ciencias Naturales y Museo, 7 Universidad Nacional de La Plata, La Plata, Buenos Aires, Argentina.

$8 \quad{ }^{2}$ Consejo Nacional de Investigaciones Científicas y Técnicas (CONICET), La Plata, Buenos

9 Aires, Argentina.

10

$11 *$ Corresponding author:

12 Diego Eduardo Gutiérrez Gregoric

13 Paseo del Bosque s $/ \mathrm{n}^{\circ}$, La Plata, Buenos Aires, B1900WFA, Argentina

14 Email address: dieguty@,fcnym.unlp.edu.ar

15

16

17 
Background. The Atlantic Forest is globally one of the priority ecoregions for biodiversity conservation. In Argentina, it is represented by the Paranense Forest, which covers a vast area of Misiones Province between the Paraná and Uruguay rivers. The Uruguay River is a global hotspot of freshwater gastropod diversity, here mainly represented by Tateidae (genus Potamolithus) and to a lesser extent Chilinidae. The family Chilinidae (Gastropoda, Hygrophila) includes 21 species currently recorded in Argentina, and three species in the Uruguay River. The species of Chilinidae occur in quite different types of habitats, but generally in clean oxygenated water recording variable temperature ranges. Highly oxygenated freshwater environments (waterfalls and rapids) are the most vulnerable continental environments. We provide here novel information on three new species of Chilinidae from environments containing waterfalls and rapids in the Uruguay River malacological province of Argentina.

Materials \& Methods. The specimens were collected in 2010. We analyzed shell, radula, and nervous and reproductive systems, and determined the molecular genetics. The genetic distance was calculated for two mitochondrial markers (cytochrome $c$ oxidase subunit I-COI- and cytochrome b-Cyt b-) for these three new species and the species recorded from the Misionerean, Uruguay River and Lower Paraná-Río de la Plata malacological provinces. In addition the COI data were analyzed phylogenetically by the neighbor-joining and Bayesian inference techniques.

38 Results. The species described here are different in terms of shell, radula and nervous and reproductive systems, mostly based on the sculpture of the penis sheath. Phylogenetic analyses grouped the three new species with those present in the Lower Paraná-Río de La Plata and 41 Uruguay River malacological provinces.

42 Discussion. Phylogenetic analyses confirm the separation between the Uruguay River and the Misionerean malacological provinces in northeast Argentina. These new endemic species from the Uruguay River add further support to the suggestion that this river is a diversity hotspot of freshwater gastropods (with 54 species present in this basin, 15 of them endemic). These endemic species from environments with rapids and waterfalls should be taken into account by government agencies before the construction of dams that modify those ecologic niches in the Uruguay River. 


\section{INTRODUCTION}

51 Highly oxygenated freshwater environments (waterfalls and rapids) are the most vulnerable continental environments globally, supporting highly specific faunas (including gastropods) with narrow habitat requirements. Accordingly, many native snail populations are declining in numbers as a consequence of the continuous degradation and destruction of their natural ecosystems from unabated human activity (Rumi et al., 2006; Strong et al., 2008; Darrigran \& Damborenea, 2011). In particular, freshwater gastropods (approximately 5\% of the world's gastropod fauna) are at a disproportionately high risk of extinction (Strong et al., 2008). Of the 310 mollusc species listed as extinct in the 2015 International-Union-for-the Conservation-ofNature (IUCN) Red List of Threatened Species (http://www.iucnredlist.org), 73 (c. 23\%) are gastropods from inland waters. The changes that result from damming rivers with waterfalls and rapids have caused the extinction of species - for example, those of the gastropod genus Aylacostoma (Mansur, 2000a, b). Despite the significance of this type of environment, the study of freshwater gastropods inhabiting waterfalls and rapids is poor (e. g. Ponder, 1982; Glöer, Albrecht \& Wilke, 2007; Gutiérrez Gregoric, Núñez \& Rumi, 2010). Vogler et al. (2014) described a new species of Aylacostoma from rapids in the High Paraná River (ArgentinaParaguay), based on materials collected in 2007. In 2011, however, the locations were flooded during the last stage of filling the Yacyretá Reservoir.

The Atlantic Forest - in Argentina represented by the Paranense Forest, occupying a large part of Misiones Province - constitutes one of the global priority ecoregions for biodiversity conservation. The orography of Misiones Province is rather accentuated and marked by a central ridge that acts as a watershed between the two great international rivers, the Paraná and the Uruguay - respectively of the Misionerean and Uruguay River malacological provinces as defined by Núñez, Gutiérrez Gregoric \& Rumi (2010). The Uruguay River is among the global hotspots of freshwater gastropod diversity according to Strong et al. (2008), within the category of "Large rivers and their first and second order tributaries". This hotspot is represented mainly by the Tateidae (genus Potamolithus, with 12 endemic species), and to a lesser extent by Chilinidae (three endemic species) and Ampullariidae (endemic genus Felipponea with three species). The streams of Misiones Province contain waterfalls and rapids that have been poorly studied by malacologists. In these environments several endemic freshwater gastropod entities 
80 have been recorded - e. g., the genera Acrorbis (Planorbidae), inhabiting only waterfall

81 environments (Hylton Scott, 1958; Ituarte, 1998; Rumi et al., 2006) and Felipponea spp.

82 (Ampullariidae), recorded in the rapids of the Uruguay River and its tributaries (Castellanos \&

83 Fernandez, 1976; Rumi et al., 2006) and the species Chilina megastoma Hylton Scott, 1958

84 (Chilinidae), inhabiting the waterfalls of Iguazú National Park (Argentina and Brazil) (Hylton

85 Scott, 1958; Ituarte, 1997), Chilina iguazuensis Gutiérrez Gregoric \& Rumi, 2008 (Chilinidae)

86 and Sineancylus rosanae (Gutiérrez Gregoric, 2012) (Planorbidae), with the last being present in

87 the rapids of the upper Iguazú River (Argentina and Brazil) (Gutiérrez Gregoric \& Rumi, 2008;

88 Gutiérrez Gregoric, 2012, 2014).

89 The family Chilinidae (Gastropoda, Hygrophila) is one of the oldest families of

90 freshwater gastropods (Duncan, 1960). Of the 21 species of the Chilina genus found in

91 Argentina, 15 are endemic and nine of this 21 are vulnerable (Rumi et al., 2006; Núñez,

92 Gutiérrez Gregoric \& Rumi, 2010). Vulnerability was assessed based on one or more of the

93 following: 1, known only from the type locality (three species); 2, no recent record (four

94 species); 3, continuous restricted distribution (six species); 4, discontinuous restricted

95 distribution (three species) (Rumi et al., 2006; Gutiérrez Gregoric \& Rumi, 2008; Gutiérrez

96 Gregoric, Ciocco \& Rumi, 2014). Of those nine vulnerable species, four are in protected areas.

97 Globally, the IUCN Red List of Threatened Species (http://www.iucnredlist.org) lists only one species as "vulnerable" (C. angusta (Philippi, 1860) from Chile), seven as "data-deficient", and

99 four as "least concern". In the Del Plata basin (containing the Paraná, Uruguay and Río de la

100 Plata rivers) six species of Chilinidae have been recorded. Three are found in the Lower Paraná-

101 Río de la Plata and the Uruguay River malacological provinces: Chilina fluminea (Maton, 1809),

102 Chilina rushii Pilsbry, 1896 and Chilina gallardoi Castellanos \& Gaillard, 1981 (Núñez,

103 Gutiérrez Gregoric \& Rumi, 2010). The other three are from the Misionerean malacological

104 province: Chilina guaraniana Castellanos \& Miquel, 1980, originally recorded in the Paraná

105 River in the area of the current Yacyretá reservoir but not having been cited since 1935, and the

106 aforementioned C. megastoma and C. iguazuensis both recorded only in the Iguazú River and its

107 tributaries (Argentina-Brazil) (Castellanos \& Gaillard, 1981; Gutiérrez Gregoric, 2008, 2010;

108 Gutiérrez Gregoric \& Rumi, 2008; Núñez, Gutiérrez Gregoric \& Rumi, 2010).

109 In this study we describe and provide information on the anatomy and molecular genetics

110 of three news species: Chilina nicolasi, Chilina santiagoi and Chilina luciae from rapids and 
111 waterfalls of the Uruguay River malacological province. Phylogenetic analyses were used to

112 confirm the segregation of the three species and of the species in the different freshwater

113 malacological provinces of Argentina.

114

115 MATERIALS AND METHODS

116 The specimens were collected in the Misiones Province (authorized by the Ministry of Ecology,

117 Natural Renewable Resources and Tourism) and deposited in the Malacological Collection at the

118 Museo de La Plata, Buenos Aires Province, Argentina (MLP-Ma). Additional material in MLP-

119 Ma was also studied. Adult specimens were first relaxed in menthol for 12 hours, then immersed

120 in hot water $\left(70^{\circ} \mathrm{C}\right)$, and finally stored in $96 \%(\mathrm{v} / \mathrm{v})$ aqueous ethanol or fixed in modified

121 Raillet-Henry (R-H) solution for freshwater animals-93\% (v/v) distilled water, 2\% (v/v) glacial

122 acetic acid, 5\% (v/v) formaldehyde, and $6 \mathrm{~g}$ sodium chloride per liter. Six shell measurements

123 were taken: total length (TL), length of the last whorl (LWL), aperture length (AL), total width

124 (TW), aperture width (AW), and aperture projection (AP) following Martín (2003; Fig. 1). For

125 anatomical studies of the reproductive and pallial systems, the methodology of Cuezzo (1997)

126 was followed. Dissections were done under a Leica MZ6 stereoscopic microscope and

127 anatomical systems drawn with the help of a camera lucida. Figures were drawn only for

128 characters that showed specific differences. The terminology used for the anatomical

129 descriptions follows Ovando \& Gutiérrez Gregoric (2012). In addition, we compared these new

130 species with species of Chilinidae for which anatomical and conchological studies have been

131 undertaken: Chilina megastoma studied by Ituarte (1997) and C. iguazuensis described by

132 Gutiérrez Gregoric \& Rumi (2008) from Misionerean malacological province, Argentina; $C$.

133 fluminea fluminea and C. fluminea parva Martens, 1868 studied by Lanzer (1997) from Río

134 Grande do Sul, Brazil: C. fluminea fluminea studied by Gutiérrez Gregoric (2008) from Lower

135 Paraná - Río de la Plata malacological province, Argentina; C. rushii and C. gallardoi studied by

136 Gutiérrez Gregoric (2010) from Uruguay river and Lower Paraná - Río de la Plata malacological

137 provinces, Argentina; C. lilloi Ovando \& Gutiérrez Gregoric, 2012, C. portillensis Hidalgo, 1880

138 and C. tucumanensis Castellanos \& Miquel, 1980 all studied by Ovando \& Gutiérrez Gregoric

139 (2012) from Middle Paraná and Central malacological provinces, Argentina; C. mendozana

140 Strobel, 1874, C. parchappii (d’Orbigny, 1835), C. cuyana Gutiérrez Gregoric, Ciocco \& Rumi, 
1412014 and C. sanjuanina Gutiérrez Gregoric, Ciocco \& Rumi, 2014 all studied by Gutiérrez

142 Gregoric, Ciocco \& Rumi (2014) from Cuyo malacological province, Argentina.

143 The radulae were separated from the buccal mass and cleaned following the method of

144 Holznagel (1998), and mounted for scanning electron microscopy. The radular-dentition formula

145 used is L-C- $-\mathrm{L}$ (number lateral teeth - central tooth- number lateral teeth; there is no distinction

146 between marginal and lateral teeth as there is in other molluscs).

147 Total DNA was extracted from c. $2 \mathrm{~mm}^{3}$ samples from the foot of recently collected

148 specimens (2010) using commercial kits (DNeasy Blood \& Tissue, for Qiagen). A partial

149 sequence of the genes encoding the mitochondrial cytochrome $c$ oxidase subunit I (COI) and

150 cytochrome b ( Cyt b) were amplified by the polymerase chain reaction (PCR) with the universal

151 primers of Folmer et al. (1994) and Merrit et al. (1998) respectively. Amplification was

152 performed in a final volume of $50 \mu 1$, following Gutiérrez Gregoric et al. $(2013,2014)$. The PCR

153 products were purified with an AxyPrep PCR Clean-up Kit (Axygen Biosciences, Union City,

154 California) and both DNA strands for each gene were then directly cycle-sequenced (Macrogen

155 Inc., Seoul, Korea). The resulting sequences were trimmed to remove the primers, and the

156 consensus sequences of the individuals were compared to reference sequences in GenBank.

157 Sequences of C. megastoma, C. iguazuensis and C. fluminea (partial) were obtained from the

158 Barcode of Life Database (BOLD). The sequence alignment was performed with the Clustal X

159 2.0.12 software (Larkin et al., 2007), optimized by visual inspection and edited with a word

160 processor. Since we obtained Cyt b sequences for only four individuals we calculated a pairwise

161 genetic divergence (Kimura two-parameter) for this region, and only COI data were subjected to

162 phylogenetic analyses by the methods of neighbor-joining (NJ) and Bayesian inference (BI). The

163 NJ analysis was conducted using MEGA 5.05 software (Tamura et al., 2011) through the use of

164 the maximum-composite-likelihood option for computing evolutionary distances (Tamura, Nei \&

165 Kumar, 2004). Statistical support for the resulting phylogeny was assessed by bootstrapping with

1661000 replicates (Felsenstein, 1985). The BI was carried out with the MrBayes 3.2 software

167 (Ronquist et al., 2012). Two runs were performed simultaneously with four Markov chains that

168 went for 1000000 generations, sampling every 100 generations. The first 10000 generations of

169 each run were discarded as burn-in, and the remaining 18000 trees were used to estimate

170 posterior probabilities. 
171 The electronic version of this article in Portable Document Format (PDF) will represent a

172 published work according to the International Commission on Zoological Nomenclature (ICZN,

173 2012), and hence the new names contained in the electronic version are effectively published

174 under the International Code of Zoological Nomenclature from the electronic edition alone. This

175 published work and the nomenclatural acts it contains have been registered in ZooBank, the

176 online registration system for the ICZN. The ZooBank LSIDs (Life Science Identifiers) can be

177 resolved and the associated information viewed through any standard web browser by appending

178 the LSID to the prefix http://zoobank.org/. The LSID for this publication is:

179 urn:lsid:zoobank.org:pub:3140E36D-B1F5-4C1B-9F3C-0081CDE88B00. The online version of

180 this work is archived and available from the following digital repositories: PeerJ, PubMed

181 Central and CLOCKSS.

182

183

RESULTS

184

Systematic account

185

Family Chilinidae Dall, 1870

186

Genus Chilina Gray, 1828

187

Type species: Auricula (Chilina) fluctuosa Gray, 1828 (subsequent designation of Gray

188 1847).

189

Diagnosis: Species in the genus and family have an oval (oblong to ventricose) shell with an

190 expanded last whorl. Nervous system with partial detorsion. Roof of the mantle cavity pigmented with kidney occupying almost entire length. Kidney inner wall with numerous transverse trabeculae of irregular contour. Rectum on right side of mantle cavity, anus near pneumostome. Incomplete division of male and female ducts; common duct opens to hermaphrodite duct, with irregular contours on both sides. Proximal portion of uterus with glandular walls. Calcareous granules in vaginal lumen and secondary bursa copulatrix or accessory seminal receptacle present. Penial terminal portion with cuticularized teeth-like structures.

Remarks: The Chilinidae includes only the genus Chilina with 36 species, 21 of which are found in Argentina (Núñez, Gutiérrez Gregoric \& Rumi, 2010; Ovando \& Gutiérrez Gregoric, 2012; Gutiérrez Gregoric, Ciocco \& Rumi, 2014) with the remainder in Chile and Brazil (Castellanos \& Gaillard, 1981; Simone, 2006; Valdovinos Zarges, 2006). 
202 Chilina nicolasi sp. nov.

203 Urn:1sid:zoobank.org:act:A7D18E3D-1CA1-470F-A5B6-3EB070C994C3

204 (Figs 2A-B, 3, 4A-E)

205 Type locality and type material: Uruguay River, Alba Posse, Misiones Province, Argentina, 206 (27³3’S; 54²0’W), coll. D.E. Gutiérrez Gregoric, V. Núñez \& R.E. Vogler, 23 March 2010. 207 Holotype: MLP-Ma 13412-2 (foot in alcohol, body in R-H, shell dry); paratypes: MLP-Ma

20813412 same data (4 specimens: foot in alcohol, body in R-H, shell dry); MLP-Ma 14134 same 209 data (10 specimens: body in R-H, shell dry).

210

211 Etymology: Dedicated to the first son, Nicolás, of the first author of this paper.

212 Diagnosis: Shell thick, oval, two columellar teeth (upper underdeveloped); radula with first

213 lateral tooth with saw-like external side of mesocone; penis sheath twice the length of the

214 prepuce; penis sheath inner sculpture with triangular regular pustules.

215 Description:

216 Shell (Fig. 2A-B). Thick, oval, periostracum light brown with weak dark reddish zigzag bands.

217 Spire immersed. Last whorl well developed. Aperture 90\% of LWL, slightly expanded, with

218 white callus of terminal portion slightly widened and flattened. Width 73\% of LWL. Aperture

219 projected $35 \%$ of TW. Two columellar teeth, lower tooth more prominent and developed than

220 upper. Dimensions: see Table 1.

221 Reproductive System (Fig. 3). (i) Female reproductive system. Bursa copulatrix duct long ( $\mathrm{N}=$

222 2; $7.0 \mathrm{~mm}, 7.3 \mathrm{~mm}$ ), five times bursa sac diameter. Bursa copulatrix sac spherical, located on left

223 side of cephalopedal haemocoel between pericardial cavity and columellar base. Secondary bursa

224 copulatrix short, emerging from base of uterus, cylindrical (c. 8\% the length of bursa copulatrix

225 duct). Vagina cylindrical, longer than wide, folded over free oviduct and entering female atrium.

226 (ii) Male reproductive system. Prostate gland extending to lower half of uterus and consisting of

227 variable size and with cylindrical acini. Vas deferens coiled twice, overlapping vagina. At level

228 of penis complex, vas deferens bent back on itself. Penis sheath muscular, twice the length of the 229 prepuce, with slight convexity on right side. Penis sheath inner sculpture with triangular pustules

230 over entire surface. Penis elongated (as long as the penis sheath), robust, with outer surface

231 crossed by transverse lamellae, triangular in cross section. Prepuce cylindrical, thin, with

232 constriction marked by oblique lines arranged in a $\mathrm{V}$ making connection with penis sheath. 
233 Radula (Fig. 4 A-E). Average number of rows $55(\mathrm{~N}=3$; range 52-59). Number of teeth per half 234 row of 40-41 ( $=3)$. Central tooth asymmetrical, bicuspid, elongated base higher than wide, left 235 cusp more developed. Both cusps with slight sawlike edges. Presence of marked longitudinal 236 groove between cusps. First and second lateral teeth tricuspid or tetracuspid, with mesocone (in 237 tricuspid, Fig. 4A) or second inner cusp (in tetracusipd, Fig. 4B) more developed and with 238 outermost edge saw-like. Outermost teeth with thin base and five to seven cusps similarly 239 developed. Radular formula: $40-1-40$ and 41-1-41.

240 Nervous system (Fig. 3C; Table 2). All connectives between ganglia relatively thin compared to 241 size of both ganglia and central nervous system. Left connective joining the cerebral ganglion 242 with the pleural ganglion longer than the right one (10.1\% vs. 9.0\% of LWL). Right

243 pleuroparietal connective passes over the penis complex. Left pleuroparietal connective shorter 244 than right (3.8\% vs $9.2 \%$ of LWL). Parietal-subesophageal connective shorter than parietal-

245 visceral connective ( $15.1 \%$ vs $23.3 \%$ of LWL). One very short connective (5.7\% of LWL)

246 linking subesophageal ganglion to visceral ganglion and closing posterior nerve ring.

247 Pleurovisceral connectives with partial detorsion characteristic of the genus.

248 Distribution (Fig. 5). Only known from the type locality.

249 DNA barcoding: The data from the analysis of the cytochrome $c$ oxidase subunit I (COI) of 655

250 bp from a paratype (MLP-Ma 14134, specimen 185) was deposited in GenBank under the 251 number KT830419.

252 Remarks: Of the Chilinidae species for which characters of the radula have been described so 253 far, C. nicolasi is the only one with the first and second lateral tooth of the outer edge of the 254 mesocone (tricuspid) or second inner cusp (tetracuspid) serrated. The radulae of C. gallardo $i$ and 255 C. nicolasi have a similar number of rows and teeth per row, but the outermost lateral teeth in $C$. 256 nicolasi can have up to seven cusps, while those of $C$. gallardo $i$ have only five (Table 3 ). The 257 radula of $C$. iguazuensis has more rows (57-65 vs 52-59) and teeth per half-row (43-63 vs 40-41) 258 than C. nicolasi (Gutiérrez Gregoric \& Rumi, 2008). Only three species, C. fluminea, C. rushii 259 and C. lilloi, have seven cusps on the outermost lateral teeth, but the number of rows is lower 260 (49, 48, and 44 respectively); and in C. fluminea and C. lilloi the central tooth is tricuspid 261 (Lanzer, 1997; Gutiérrez Gregoric, 2008; Ovando \& Gutiérrrez Gregoric, 2012). The shells of $C$. 262 gallardoi and C. nicolasi have two columellar teeth in the aperture, but in C. gallardoi both teeth 263 are strong (as occurs in C. fluminea and C. rushii). The AL/LWL ratio in C. gallardoi is lower 
264 than in C. nicolasi (78\% vs $89 \%$ : Gutiérrez Gregoric, 2010) while in C. iguazuensis it is greater

265 (100\%; Gutiérrez Gregoric \& Rumi 2008). In addition, C. gallardoi has a keel (or sub-keel)

266 along the whorls (as does $C$. rushii), a character absent in C. nicolasi (and all other species).

267

268 Chilina santiagoi sp. nov.

269 LSIDurn:lsid:zoobank.org:act:4238E0F8-4452-4818-A1F2-7C1A5D8FFC4E

270 (Figs 2C-D, 4F-H, 6)

271 Type locality and type material: Horacio Foerster Falls, Misiones Province, Argentina

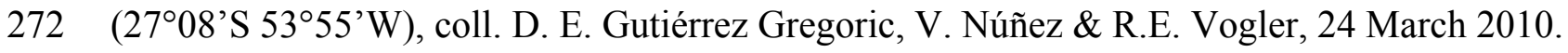

273 Holotype: MLP-Ma 14135 (body in R-H, shell dry); paratypes: MLP-Ma 13417 same data (five

274 specimens in alcohol); MLP-Ma 14136 same data (six specimens: body in R-H, shell dry).

275 Other material examined: MLP-Ma 14137 Horacio Foerster Falls, Misiones Province,

276 Argentina ( $27^{\circ} 08^{\prime} \mathrm{S} 53^{\circ} 55^{\prime} \mathrm{W}$ ), coll. C. Galliari, May 2009 (four dry shells); MLP-Ma 14138

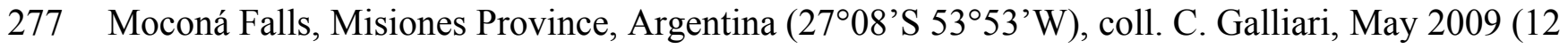

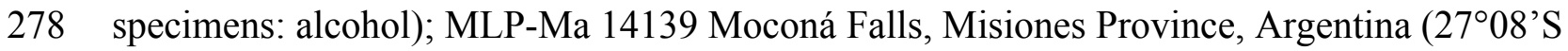

$27953^{\circ} 53^{\prime}$ W), coll. A. Rumi, S.M. Martín \& I. César, October 20, 2011 (10 specimens: body in R-

280 H, shell dry); MLP-Ma 14140 Yerba Falls, Paraíso Stream, El Soberbio, Misiones Province,

281 Argentina ( $\left.27^{\circ} 14^{\prime} \mathrm{S} 54^{\circ} 02^{\prime} \mathrm{W}\right)$, no collector and date (two specimens: alcohol)

282 Etymology: Dedicated to the second son, Santiago, of the first author of this paper.

283 Diagnosis: Shell small, thin, aperture projection $50 \%$ of TW; radula with asymmetrical bicuspid

284 central tooth; penis sheath inner sculpture with regular conical pustules and longitudinal folds.

285 Description:

286 Shell (Fig. 2C-D). Small, thin, oval, of 31/4 whorls. Spire low and conical. Last whorl large (97\%

287 of the total length). Width $80 \%$ of LWL. Aperture expanded, $94.5 \%$ of LWL, with strong white

288 callus. One columellar tooth. Aperture projection 50\% of TW. Light brown periostracum with

289 strong thin longitudinal reddish bands. Dimensions: see Table 1.

290 Reproductive System (Fig. 6). (i) Female reproductive system. Bursa copulatrix duct (average

$2914.5 \mathrm{~mm}$; range 4.1-5.3; $\mathrm{N}=4$ ) nine times bursa sac diameter. Bursa copulatrix sac oval.

292 Secondary bursa copulatrix long (c. 18\% the length of bursa copulatrix duct), comprising of a

293 long duct and expanded at the distal end. (ii) Male reproductive system. Muscular penis sheath,

294 nearly twice as long as prepuce. Penis sheath inner sculpture with pustules of conical aspect and 
295 longitudinal folds. Penis slightly longer than penis sheath, robust, with outer surface cut by 296 transverse lamellae, triangular in cross-section. Prepuce inner sculpture with numerous smooth, 297 very tight longitudinal folds.

298 Radula (Fig. 4F-H). Average number of rows $44(\mathrm{~N}=3$; range 43-44). Number of teeth per half 299 row 32-33 $(\mathrm{N}=3)$. Central tooth asymmetrical, bicuspid, elongated base higher than wide, right 300 cusp more developed and serrated, with weak longitudinal groove between the two cusps. First 301 lateral tooth tricuspid with mesocone more developed, base of tooth same width as apical part

302 (cusp area). Second lateral tooth tricuspid (mainly) or tetracuspid, with mesocone (of the 303 tricuspid) or the outermost second cusp (in the tetracuspid) more developed, base of tooth

304 narrower than apical part of tooth. Outermost teeth with thin base, having five similarly

305 developed cusps. Radular formula: $32-1-32$ and 33-1-33.

306 Nervous system (Fig. 6 Table 2). Left connective joining the cerebral ganglion with the pleural 307 ganglion slightly longer than the right one (12.2\% vs. $11.2 \%$ of LWL). Left pleuroparietal 308 connective shorter than right one ( $4.5 \%$ vs $12.8 \%$ of LWL). Long connective ( $19.3 \%$ of LWL)

309 linking left parietal ganglion to subesophageal ganglion, located above posterior half of 310 columellar muscle. Long connective ( $20.1 \%$ of LWL) linking right parietal ganglion to visceral 311 ganglion. One very short connective (3.5\% of LWL) linking subesophageal ganglion to visceral 312 ganglion and closing posterior nerve ring.

313 Distribution (Fig. 5). Horacio Foerster Falls is in the Yabotí Biosphere Reserve. It is a small 314 waterfall on the Oveja Negra Stream, which flows into the Uruguay River. Water quality

315 parameters of the Horacio Foerster Falls measured 24 March 2010, were: water temperature 23.2

$316{ }^{\circ} \mathrm{C}$; pH 7.62; dissolved oxygen $6.3 \mathrm{mg} / 1$; conductivity $0.015 \mathrm{mS}$. Moconá Falls is in the Moconá

317 Provincial Park, which is also in the Yabotí Biosphere Reserve. This waterfall is peculiar in the

318 sense that it spills along a ridge parallel to the river course. Its height varies with the level of the

319 river and it is the second largest waterfall in Misiones Province after the Iguazú Falls.

320 DNA barcoding: The data from the analysis of the cytochrome $c$ oxidase subunit I (COI) of 655

321 bp and cytochrome b (Cyt b) of 388 bp from a paratype (MLP-Ma 14136, specimen 6) were

322 deposited in GenBank under the numbers KT820416 and KT820424 respectively.

323 Remarks: The spire is not preserved in all specimens. This loss occurs in several species of

324 Chilinidae, especially in those that inhabit fast-running water such as C. iguazuensis (Gutiérrez

325 Gregoric \& Rumi, 2008). Chilina megastoma, which inhabits waterfall environments, differs 
326 from C. santiagoi mainly in size reaching a maximum last whorl length of $9.6 \mathrm{~mm}$, whereas that 327 of C. megastoma is up to $17.3 \mathrm{~mm}$ (Gutiérrez Gregoric, 2008). Chilina megastoma has a striated 328 shell, which C. santiagoi does not, and two columellar teeth, while there is one in C. santiagoi.

329 Both species have thin shells. In C. megastoma there is a slight swelling not forming a true 330 ganglion between the left pleural and the subesophageal ganglia (Ituarte, 1997; Gutiérrez

331 Gregoric, 2010), but this was not detected in C. santiagoi. Compared with C. nicolasi, the shell

332 of C. santiagoi is thinner, has a conical and low spire (inmersed in C. nicolasi), strong rather 333 than weak bands, higher AL/LWL, AP/TW and TW/LWL ratios ( $94.5 \%$ vs $90 \%, 50 \%$ vs $34 \%$, $33480 \%$ vs $73 \%$, respectively), and has one columellar tooth whereas there are two in C. nicolasi.

335 Chilina santiagoi differs from C. nicolasi in the length of the secondary bursa copulatrix (18\% of

336 bursa copulatrix duct length vs $8 \%$ ), and internal sculpture of the penis sheath (conical and

337 longitudinal pustules vs triangular pustules). Regarding the radula, C. santiagoi has fewer rows

338 of teeth (average 44 vs 55 in C. nicolasi) and fewer teeth per half row (average 32 vs 40); the

339 developed cusp of the central tooth (in both the tooth is bicuspid) is the right cusp (left in $C$.

340 nicolasi) and the cusp has only one serrated edge (both in C. nicolasi), and the outermost lateral

341 teeth have five cusps (up to seven in C. nicolasi).

342

343 Chilina luciae sp. nov.

344 LSIDurn:lsid:zoobank.org:act:FE46F318-BA47-4D5B-8AD2-266C63EB87A4

345 (Figs. 2E-F; 4I-K; 7)

346 Type locality and type material: Pesiguero stream, Misiones Province, Argentina (27 $58^{\prime} \mathrm{S}$

347 55²6’W), coll. D. E. Gutiérrez Gregoric, March 21, 2010.

348 Holotype: MLP-Ma 14141 (alcohol); Paratypes: MLP-Ma 13413 same data (5 specimens: foot in

349 alcohol, body R-H, shell dry); MLP-Ma 14142 same data (4 specimens: alcohol).

350 Etymology: Dedicated to the daughter, Lucía, of the first author of this paper.

351 Diagnosis: Shell thick, aperture projection 33\% of TW; radula, central tooth bicuspid and with

352 saw-like external side, first lateral tetracuspid; prepuce $37 \%$ of length of penis sheath; penis

353 sheath inner sculpture with two regions, one with polygonal pustules and the other with

354 longitudinal zigzag folds.

355 Description: 
356 Shell (Fig. 2E-F). Thick, slightly elongated. Spire eroded. Width 74\% of LWL. Aperture

357 somewhat expanded, of $83 \%$ of LWL, with strong white callus. Two strong columellar teeth.

358 Aperture projection 33\% of TW. Light reddish periostracum with some dark brown spots.

359 Dimensions: see Table 1.

360 Reproductive System (Fig. 7). (i) Female reproductive system. Bursa copulatrix duct (average

$3614.7 \mathrm{~mm}$; range 4.5-4.8; $\mathrm{N}=3$ ) four times bursa sac diameter. Bursa copulatrix sac spherical.

362 Secondary bursa copulatrix short (c. 11\% of the length of bursa copulatrix duct), cylindrical,

363 expanded at its distal portion. (ii) Male reproductive system. Muscular penis sheath, a little more

364 than twice the length of prepuce $(2.1 \mathrm{~mm}$ vs $0.8 \mathrm{~mm})$. Penis sheath inner sculpture with

365 polygonal pustules and longitudinal zigzag folds. Penis $92 \%$ the length of penis sheath, robust,

366 with outer surface crossed by transverse lamellae, triangular in cross section. Inner sculpture of

367 prepuce with numerous smooth, very tight longitudinal folds.

368 Radula (Fig. 4I-K). Number of rows $50(\mathrm{~N}=2)$. Number of teeth per half row 40-41 $(\mathrm{N}=2)$.

369 Central tooth asymmetrical, bicuspid, elongated base higher than wide, both cusps with serrated

370 edges. First lateral tooth tetracuspid with innermost second cusp more developed, base of tooth

371 same width as apical part (cusp area). Second lateral tooth tetracuspid, with innermost second

372 cusp more developed, base of tooth narrower than apical part of tooth. Outermost teeth with thin

373 base, having five similarly developed cusps. Radular formula: $40-1-40$ and $41-1-41$.

374 Nervous System (Fig. 7; Table 2). Left connective joining the cerebral ganglion with the pleural

375 ganglion longer than the right one ( $10.3 \%$ vs. $8.8 \%$ of LWL). Left pleuroparietal connective

376 smaller than the right one ( $5.9 \%$ vs $17.7 \%$ of LWL). Long connective ( $22.1 \%$ of LWL) linking

377 left parietal ganglion to subesophageal ganglion, located above posterior half of columellar

378 muscle. Long connective (16.2\% of LWL) linking right parietal ganglion to visceral ganglion.

379 One very short connective (3.5\% of LWL) linking subesophageal ganglion to visceral ganglion

380 and closing posterior nerve ring.

381 Distribution (Fig. 5). Only known from the type locality. Pesiguero Stream drains into the

382 Uruguay River and is in the Concepción de la Sierra District of Misiones Province. The Uruguay

383 River is $10 \mathrm{~km}$ from the collection site.

384 DNA barcoding: The data from the analysis of the cytochrome $c$ oxidase subunit I (COI) of 655

385 bp and cytochrome b (Cyt b) of 388 bp from a paratype (MLP-Ma 14142, specimen 186) were

386 deposited in GenBank under the numbers KT820420 and KT820425 respectively. 
387 Remarks: Chilina luciae, like C. gallardoi and C. rushii, was recorded in the rapids of a stream 388 that flows into the Uruguay River. Chilina luciae differs from both those species by not having a 389 shell keel. Chilina luciae has two strong columellar teeth as in C. gallardoi, C. fluminea and C. rushii; while $C$. nicolasi also has two columellar teeth, but weak ones. The AL/LWL ratio in $C$. luciae is lower than in C. nicolasi and C. santiagoi ( $83 \%$ vs $90 \%$ and $95 \%$ respectively), but higher than in C. gallardoi (78\%) (Gutiérrez Gregoric, 2010). The AP/TW and TW/LWL ratios in C. luciae and C. nicolasi are similar (33\% vs $35 \%$ and $74 \%$ vs $73 \%$, respectively) and all lower than in C. santiagoi (50\% and $80 \%$ respectively). Chilina luciae differs from C. nicolasi and C. santiagoi in the length of the secondary bursa copulatrix (11\% of bursa copulatrix duct length vs $8 \%$ and $18 \%$ respectively), and internal sculpture of the penis sheath (polygonal and zigzag longitudinal pustules vs triangular pustules and conical and longitudinal pustules, respectively. The radula of $C$. luciae has similarities and differences with other species, but in no case is equal to any of them (Table 3; Gutiérrez Gregoric, 2010; Ovando \& Gutiérrez Gregoric 2012; Gutiérrez Gregoric, Ciocco \& Rumi, 2014). The first lateral tooth of C. luciae is tetracuspid like in C. fluminea (Gutiérrez Gregoric, 2010).

402

\section{Molecular analyses}

404

Four novel sequences of 388 bp for Cyt b (C. nicolasi, 1; C. luciae, 1; C. fluminea, 1; C. gallardoi, 1) and 15 sequences of 655 bp for COI (C. nicolasi, 1; C. santiagoi, 1; C. luciae, 1; C. fluminea, 5; C. rushii, 1; C. gallardoi, 1; C. iguazuensis, 4; C. megastoma, 1) were obtained (Table 4). BLAST searches identified Cyt b and COI sequences as similar to other Hygrophila, ruling aout possible contamination with DNA from other sources.

The COI sequences obtained here for Chilina nicolasi and C. santiagoi differ by c. 1.2\%, while those of $C$. luciae differ from the other two species described in this work by $3.8 \%$ (Table 411 5). The two phylogenetic analyses (Fig. 8) recovered two well-supported sister clades with high 412 posterior probabilities and bootstrap values. Both analyses showed two groups within the 413 Chilinidae species, one belonging to the Misionerean malacological province and the other 414 representatives from the other two malacological provinces (Uruguay River and Lower Paraná415 Río de la Plata). 
418 Distances of both new species from the other two species from which this gene was sequenced

419 are similar (Table 6).

420

\section{DISCUSSION}

422 This report provides anatomical, molecular-genetic, and distributional information on the species 423 of Chilina of lotic environments from the Uruguay River malacological province, increasing the 424 number of known freshwater gastropod species in this province from 51 to 54 . This province 425 exhibits the highest freshwater gastropod richness in Argentina, and contains the highest number 426 of vulnerable (14) and endemic species (15) (Núñez, Gutiérrez Gregoric \& Rumi, 2010). These new endemic species from the Uruguay River add further support to the suggestion that this river is a diversity hotspot of freshwater gastropods (Strong et al., 2008). The family Chilinidae is now represented by 24 species in Argentina, of which 17 are endemic.

430 From an anatomical viewpoint, the new species exhibit differences in shell, radula and reproductive system characteristic, especially in the sculpture of the penis sheath. In species recently described and re-described by Ovando \& Gutiérrez Gregoric (2012) and Gutiérrez Gregoric, Ciocco \& Rumi (2014) differences in the above characters were also found.

The interspecific genetic distances found in the present study for COI were $1.2 \%$ or greater, and the intraspecific distances lower than $0.5 \%$. Studies in Lymnaeidae (Gastropoda, Hygrophila) have suggested a similar interspecific genetic distance for COI among neotropical species (Correa et al., 2011). For land molluscs, Davison et al. (2009) estimated interspecific genetic distances of $12 \%$ and intraspecific of $3 \%$, but noted that the interspecific genetic distances can also be quite low, around $1 \%$. For this reason, we suggest that an integrative vision is necessary - one that complements conchological and anatomical information with molecular genetics and ecological data.

The phylogenetic analyses of Chilinidae confirmed segregation of the freshwater gastropod fauna of Misiones Province from those of other provinces, as suggested by Núñez, Gutiérrez Gregoric \& Rumi (2010). The species described here from the Uruguay River malacological province are distinct from those of the Misionerean malacological province, e. g. C. megastoma and C. iguazuensis. Nevertheless, the species from the Río de la Plata River (C. fluminea and $C$. rushii) are more closely associated with those of the Uruguay River. The species in the Cuyo malacological province (C. mendozana and C. sanjuanina) are distinct from those from the Del 
449 Plata basin. Likewise, species of Aylacostoma (Thiaridae) and Acrorbis (Planorbidae) in the 450 Misioneran malacological province have not been recorded in the Uruguay River malacologial 451 province (Núñez, Gutiérrez Gregoric \& Rumi, 2010). Despite malacological differences, 452 ichthyological classifications (Ringuelet, 1975; López, Morgan \& Montenegro, 2002) suggest 453 that Misiones Province (as a political division) should be considered in its entirety as an 454 ecoregion.

455 With the examples described here, the number of endemic species known in waterfall 456 environments increases. Thus, species living in Misiones Province are Chilina megastoma, 457 endemic to Iguazú National Park, Acrorbis petricola, from the waterfalls of Iguazú National Park 458 and the Encantado Falls (Aristólubo del Valle), and Chilina santiagoi in the Uruguay River. In 459 addition, $C$. nicolasi and $C$. luciae have been added to the species recorded in rapids along rivers 460 in Misiones Province, which include C. iguazuensis, Sineancylus rosanae, Felipponea spp. and 461 Aylacostoma spp. A hydroelectric dam is going to be built in the area where C. nicolasi were 462 collected. This hydroelectric dam will raise the level the Uruguay River, causing the 463 disappearance of the environment inhabited by the species. These endemic species should be 464 taken into account by government agencies before the construction of dams that modify these 465 types of environments in the Uruguay River.

\section{ACKNOWLEGMENTS}

468 We thank the curator and technical staff of the malacological collection of La Plata Museum 469 (MLP) G. Darrigran and M. Tassara for their generosity in lending the material under study, and 470 R. Vogler, V. Núñez, and A. Rumi for support during field work. We are especially grateful to 471 Dr. M. Griffin, Dr. R. Cowie and Dr. C. Lydeard for her helpful comments. Dr. D.F. Haggerty, a 472 retired academic career investigator and native English speaker, edited the final draft of the 473 manuscript 


\section{REFERENCES}

477 Castellanos ZJD, Fernández D. 1976. Ampullariidae. In: Ringuelet RA, ed. Fauna de Agua

478 Dulce de la República Argentina, Buenos Aires: Fundación para la Educación, la Ciencia y la

479 Cultura 15(1): 1-33 (in Spanish).

480 Castellanos ZJD, Gaillard MC. 1981. Chilinidae. In: Ringuelet RA, ed. Fauna de Agua Dulce de

481 la República Argentina, Buenos Aires: Fundación para la Educación, la Ciencia y la Cultura

482 15(4): 23-51 (in Spanish).

483 Correa AC, Escobar JS, Noya O, Velásquez LE, González-Ramírez C, Hurtrez-Boussès S,

484 Pointier JP. 2011. Morphological and molecular characterization of Neotropic Lymnaeidae

485 (Gastropoda: Lymnaeoidea), vectors of fasciolosis. Infection, Genetics and Evolution 11:

486 1978-1988.

487 Cuezzo MG. 1997. Comparative anatomy of three species of Epiphragmophora Doering, 1874

488 (Pulmonata: Xanthonychidae) from Argentina. The Veliger 40: 216-227.

489 Dall WH. 1870. On the genus Pompholyx and its allies, with a revision of the Limnaeidae of

$490 \quad$ authors. Annals of the Lyceum of Natural History of New York 9: 333-361

491 Darrigran G, Damborenea C. 2011. Ecosystem engineering impact of Limnoperna fortunei in

492 South America. Zoological Science 28: 1-7.

493 Davison A, Blackie RLE, Scothern GP. 2009. DNA barcoding of Stylommatophoran land snails:

494 a test of existing sequences. Molecular Ecology Resources 9: 1092-1101.

495 Duncan CJ, 1960. The evolution of the pulmonate genital systems. Proceedings of the Zoological 496 Society of London 134: 601-609.

497 Felsenstein J. 1985. Confidence limits on phylogenies: an approach using the bootstrap.

$498 \quad$ Evolution 39: 783-791.

499 Folmer O, Black M, Hoeh W, Lutz R, Vrijenhoek R. 1994. DNA primers for amplification of

500 mitochondrial cytochrome $c$ oxidase subunit I from diverse metazoan invertebrates.

501 Molecular Marine Biology and Biotechnology 3: 294-299.

502 Glöer P, Albrecht C, Wilke T. 2007. Enigmatic distribution patterns of the Bithyniidae in the

503 Balkan Region (Gastropoda: Rissooidea). Mollusca 25: 13-22.

504 Gray JE. 1828. Spicilegia Zoologica, or original figures and short systematic descriptions of new 505 and unfigured animals. Pt 1. London: Treuttel, Würtz \& Co. 
506 Gray JE. 1847. A list of the genera of recent Mollusca, their synonyms and types. Proceedings of 507 the Zoological Society of London 15: 129-219.

508 Gutierrez Gregoric DE. 2008. Estudios morfoanatómicos y tendencias poblacionales en especies

509 de la familia Chilinidae Dall, 1870 (Mollusca: Gastropoda) en la Cuenca del Plata.

510 Unpublished D. Nat. Thesis, Facultad de Ciencias Naturales y Museo, Universidad Nacional

511 de La Plata, 174 pp (in Spanish).

512 Gutierrez Gregoric DE. 2010. Redescription of two endemic species of Chilinidae (Gastropoda:

513 Basommatophora) from Del Plata basin (South America). Journal of Conchology 40: 321-

514332.

515 Gutierrez Gregoric DE. 2012. Anancylus rosanae (Gastropoda: Pulmonata), new genus and new

516 species from Iguazú National Park, Argentina. Malacologia 55: 107-115.

517 Gutierrez Gregoric DE. 2014. Sineancylus nom. nov. a replacement name for Anancylus

518 Gutiérrez Gregoric, 2012 (Gastropoda, Ancylidae). Malacologia 56: 243.

519 Gutierrez Gregoric DE, Rumi A. 2008. Chilina iguazuensis (Gastropoda: Chilinidae), new

520 species from Iguazú National Park, Argentina. Malacologia 50: 321-330.

521 Gutiérrez Gregoric DE, Núñez V, Rumi A. 2010. Populational studies in a endemic gastropod

522 species of waterfalls environment. American Malacological Bulletin 28: 159-165.

523 Gutiérrez Gregoric DE, Beltramino AA, Vogler RE, Cuezzo MG, Núñez V, Gomes ZR,

524 Virgillito M, Miquel SE. 2013. First records of four exotic slugs in Argentina. American

525 Malacological Bulletin 31: 245-256.

526 Gutierrez Gregoric DE, Ciocco NF, Rumi A. 2014. Two new species of Chilina Gray from Cuyo

527 Malacological Province, Argentina. (Gastropoda: Hygrophila: Chilinidae). Molluscan

$528 \quad$ Research 34: 84-97.

529 Holznagel WE. 1998. A nondestructive method for cleaning gastropod radulae from frozen,

530 alcohol-fixed, or dried material. American Malacological Bulletin 14: 181-183.

531 Hylton Scott MI 1958. Nueva especie de Chilina del norte Argentino. Neotropica 4: 26-27 (in

532 Spanish).

533 ICZN [International Commision on Zoological Nomencalture]. 2012. Amendment of Articles 8,

$5349,10,21$ and 78 of the International Code of Zoological Nomenclature to expand and refine

535 methods of publication. Zootaxa 3450: 1-7. 
536 Ituarte CF. 1997. Chilina megastoma Hylton Scott, 1958 (Pulmonata: Basommatophora): a study

537

538

539

540

541

542

543

544

545

546

547

548

549

550

551

552

553

554

555

556

557

558

559

560

561

562

563

564 on topotypic specimens. American Malacological Bulletin 14: 9-15.

Ituarte CF. 1998. Acrorbis petricola Odhner, 1937 (Gastropoda: Pulmonata: Planorbidae) at Iguazú, Misiones, Argentina, and the rediscovery of the type series of Acrorbis odhneri Hylton-Scott, 1960. The Nautilus 112: 103-108.

Lanzer, R. 1997. Chilina (Basommatophora; Chilinidae) nas lagoas costeiras do Río Grande do Sul, Brasil: concha, rádula, habitat e distribuicao. Iheringia 82: 93-106.

Larkin MA, Blackshields G, Brown NP, Chenna R, Mcgettigan PA, Mcwilliam H, Valentin F, Wallacw IM, Wilm A, Lopez R, Thompson JD, Gibson TJ, Higgins DG. 2007. Clustal W and Clustal X version 2.0. Bioinformatics 23: 2947-2948.

López HL, Morgan C, Montenegro MJ. 2002. Ichthyological ecoregions of Argentina. Probiota 1: $1-70$.

Mansur MCD. 2000a. Aylacostoma guaraniticum. IUCN 2011. IUCN Red List of Threatened Species. Version 2011.1. http//www.iucnredlist.org; last consult: 18.VII.2011.

Mansur MCD. 2000b. Aylacostoma stigmaticum. IUCN 2011. IUCN Red List of Threatened Species. Version 2011.1. http// www.iucnredlist.org; last access: 18.VII.2011.

Martín PR. 2003. Allometric growth an interpopulation morphological variation of the freshwater snail Chilina parchappii (Gastropoda: Chilinidae) in the Napostá Grande stream, southern Pampas, Argentina. Studies in Neotropical Fauna and Environment 38: 71-78.

Merritt TJS, Shi L, Chase MC, Rex MA, Etter RJ, Quattro JM. 1998. Universal cytochrome b primers facilitate intraspecific studies in molluscan taxa. Molecular Marine Biology and Biotechnology 7: 7-11.

Núñez V, Gutiérrez Gregoric DE, Rumi A. 2010. Freshwater gastropod provinces from Argentina. Malacologia 53: 47-60.

Ovando XMC, Gutiérrez Gregoric DE. 2012. Systematic revision of Chilina Gray (Gastropoda: Pulmonata) from northwestern Argentina and description of a new species. Malacologia 55: $117-134$.

Ponder WF. 1982. Hidrobiidae of Lord Howe Island (Mollusca: Gastropoda: Prosobranchia). Australian Journal of Marine and Freshwater Research 33: 89-159. 
565 Ringuelet RA. 1975. Zoogeografía y ecología de los peces de aguas continentales de la

566

567

568

569

570

571

572

573

574

575

576

577

578

579

580

581

582

583

584

585

586

587

588 Argentina y consideraciones sobre áreas ictiológicas de América del Sur. Ecosur 2(3): 1-122 (in Spanish).

Ronquist F, Teslenko M, van der Mark P, Ayres DL, Darling A, Höhna S, Larget B, Liu L, Suchard MA, Huelsenbeck JP. 2012. MrBayes 3.2: efficient bayesian phylogenetic inference and model choice across a large model space. Systematic Biology 61: 539-542.

Rumi A, Gutiérrez Gregoric DE, Núñez V, Cesar I, Roche MA, Tassara MP, Martín SM, López Armengol MF. 2006. Freshwater Gastropoda from Argentina: species richness, distribution patterns, and an evaluation of endangered species. Malacologia 49: 189-208.

Simone LRL. 2006. Land and freshwater mollusks of Brazil. EGB, Fapesp. São Paulo, 390 pp.

Strong EE, Gargominy O, Ponder WF, Bouchet P. 2008. Global diversity of gastropods (Gastropoda; Mollusca) in freshwater. Hydrobiologia 595:149-166.

Tamura K, Nei M, Kumar S. 2004. Prospects for inferring very large phylogenies by using the Neighbor-Joining method. Proceedings of the National Academy of Sciences 101: 1103011035.

Tamura K, Peterson D, Peterson N, Stecher G, Nei M, Kumar S. 2011. MEGA5: molecular evolutionary genetics analysis using maximum likelihood, evolutionary distance, and maximum parsimony methods. Molecular Biology and Evolution 28: 2731-2739.

Valdovinos Zarges C. 2006. Estado de conocimiento de los gastrópodos dulceacuícolas de Chile. Gayana 70: 88-95 (in Spanish).

Vogler RE, Beltramino AA, Peso, JG, Rumi A. 2014. Threatened gastropods under the evolutionary genetic species concept: redescription and new species of the genus Aylacostoma (Gastropoda: Thiaridae) from High Paraná River (Argentina-Paraguay). Zoological Journal of the Linnean Society 172: 501-520. 
590 Table 1 Average and range of five measurements for Chilina nicolasi sp. nov., C. santiagoi sp. 591 nov., and C. luciae sp. nov., with specific measurements of the holotypes. LWL: last whorl 592 length; AL: aperture length; TW: total width; AW: aperture width; AP: aperture projection.

\begin{tabular}{|c|c|c|c|c|c|c|}
\hline & & LWL & AL & TW & AW & AP \\
\hline \multirow[t]{5}{*}{ Chilina nicolasi $(\mathrm{n}=15)$} & Holotype & 13.50 & 11.99 & 9.76 & 7.96 & 3.39 \\
\hline & Mean & 13.16 & 11.74 & 9.63 & 7.45 & 3.41 \\
\hline & SD & 1.4 & 1.16 & 1.11 & 0.88 & 0.56 \\
\hline & Max & 16.46 & 14.26 & 12.2 & 9.49 & 4.93 \\
\hline & Min & 10.84 & 9.69 & 8.08 & 6.34 & 2.46 \\
\hline \multirow[t]{5}{*}{ Chilina santiagoi $(\mathrm{n}=40)$} & Holotype & 8.47 & 7.96 & 6.37 & 5.15 & 2.9 \\
\hline & Mean & 7.17 & 6.77 & 5.68 & 4.56 & 2.83 \\
\hline & SD & 1.33 & 1.29 & 0.96 & 0.79 & 0.55 \\
\hline & Max & 9.6 & 9.04 & 7.76 & 6.08 & 4.00 \\
\hline & Min & 4.55 & 4.3 & 3.75 & 3.00 & 1.70 \\
\hline \multirow[t]{5}{*}{ Chilina luciae $(\mathrm{n}=10)$} & Holotype & 10.62 & 8.91 & 7.84 & 5.91 & 2.53 \\
\hline & Mean & 11.54 & 9.56 & 8.51 & 6.15 & 2.78 \\
\hline & SD & 0.86 & 0.68 & 0.71 & 0.46 & 0.25 \\
\hline & Max & 12.91 & 10.56 & 9.82 & 7.24 & 3.09 \\
\hline & Min & 10.54 & 8.77 & 7.65 & 5.57 & 2.38 \\
\hline
\end{tabular}


594 Table 2 Ratio between the lengths of ganglia and last whorl in Chilina nicolasi $(\mathrm{n}=5), C$.

595 santiagoi $(\mathrm{n}=5)$ and C. luciae $(\mathrm{n}=4)$.

\begin{tabular}{llllllllll}
\hline & \multicolumn{3}{c}{ Chilina nicolasi } & \multicolumn{3}{c}{ Chilina santiagoi } & \multicolumn{3}{c}{ Chilina luciae } \\
& Ratio & Mean & SD & Ratio & Mean & SD & Ratio & Mean & SD \\
\hline lc - rc & 14.39 & 1.83 & 0.19 & 19.46 & 1.41 & 0.11 & 16.88 & 1.90 & 0.14 \\
lpe - rpe & 6.46 & 0.82 & 0.05 & 6.16 & 0.45 & 0.03 & 5.26 & 0.59 & 0.19 \\
lc - lpl & 10.10 & 1.28 & 0.07 & 12.20 & 0.88 & 0.17 & 7.11 & 0.80 & 0.26 \\
rc - rpl & 8.97 & 1.14 & 0.07 & 11.24 & 0.81 & 0.14 & 8.40 & 0.95 & 0.01 \\
c - p & 12.32 & 1.56 & 0.22 & 17.30 & 1.25 & 0.56 & 13.05 & 1.47 & 0.62 \\
rpl - rp & 9.22 & 1.17 & 0.29 & 12.80 & 0.93 & 0.13 & 14.01 & 1.58 & 0.31 \\
lpl - lp & 3.79 & 0.48 & 0.11 & 4.50 & 0.33 & 0.06 & 5.14 & 0.58 & 0.09 \\
lp - so & 15.08 & 1.91 & 0.18 & 19.35 & 1.40 & 0.20 & 17.25 & 1.94 & 0.38 \\
rp - v & 23.26 & 2.95 & 0.37 & 20.11 & 1.45 & 0.24 & 17.51 & 1.97 & 0.14 \\
so - v & 5.72 & 0.73 & 0.14 & 3.46 & 0.25 & --- & 4.21 & 0.47 & 0.14
\end{tabular}

596 Abbreviations for each ganglion: c, cerebral; lc, left cerebral; lp, left parietal; lpe, left pedal; lpl,

597 left pleural; p, pedal; rc, right cerebral; rp, right parietal; rpe, right pedal; rpl, right pleural; so, 598 subesophageal; $\mathrm{v}$, visceral. Measurements in $\mathrm{mm}$. 
601 Table 3 Radulae of Chilinidae species. NR: number of rows; CT: number of cusps of central 602 tooth; FLT: number of cusps of first lateral tooth; OT: number of cusps of outermost teeth; wd: 603 without data.

\begin{tabular}{|c|c|c|c|c|c|}
\hline Species & Formula & NR & $\mathrm{CT}$ & FLT & $\mathrm{OT}$ \\
\hline C. nicolasi & $40-1-40$ or $41-1-41$ & $52-59$ & 2 & $3-4$ & $5-7$ \\
\hline C. santiagoi & $32-1-32$ or $33-1-33$ & $43-44$ & 2 & 3 & 5 \\
\hline C. luciae & $40-1-40$ or $41-1-41$ & 50 & 2 & 4 & 5 \\
\hline C. cuyana & $38-1-38$ & 48 & 3 & $3-4$ & 5 \\
\hline C. fluminea fluminea & $30-1-30$ to $34-1-34$ & 49 & 3 & $3-4$ & $5-7$ \\
\hline C. fluminea parva & $36-1-36$ to $43-1-43$ & wd & 3 & $3-4$ & $4-8$ \\
\hline C. iguazuensis & $43-1-43$ to $63-1-63$ & $57-65$ & 2 & 3 & 5 \\
\hline C. gallardoi & $44-1-44$ & 58 & 2 & 3 & $4-5$ \\
\hline C. megastoma & $42-1-42$ & 49 & 2 & 3 & 4 \\
\hline C. mendozana & $37-1-37$ to $43-1-43$ & $39-43$ & 2 & $3-4$ & $4-5$ \\
\hline C. lilloi & $39-1-39$ to $43-1-43$ & $42-46$ & 3 & $3-4$ & $5-7$ \\
\hline C. parchappii & $31-1-31$ to $39-1-39$ & $46-49$ & 4 & $3-4$ & 5 \\
\hline C. portillensis & $38-1-38$ to $41-1-41$ & $50-57$ & 2 & 3 & $4-5$ \\
\hline C. rushii & $35-1-35$ & 48 & 2 & 3 & $5-7$ \\
\hline C. sanjuanina & $34-1-34$ or $36-1-36$ & $41-48$ & 2 & 3 & 5 \\
\hline C. tucumanensis & $36-1-36$ to $43-1-43$ & $46-58$ & 3 & $3-4$ & $4-5$ \\
\hline
\end{tabular}

604

605 
606 Table 4 Information on the specimens of Chilina used in DNA sequence analysis, with 607 a lymnaeid for comparison.

608

\begin{tabular}{|c|c|c|c|}
\hline \multirow[t]{2}{*}{ Species } & \multirow[t]{2}{*}{ Site / Malacological Province } & \multicolumn{2}{|c|}{ GenBank } \\
\hline & & $\mathrm{COI}$ & Cyt b \\
\hline Chilina nicolasi & Alba Posse / III & KT830419* & -- \\
\hline Chilina santiagoi & H. Foerster Falls / III & KT820418* & KT820424* \\
\hline Chilina luciae & Pesiguero Stream / III & KT820420* & KT820425* \\
\hline Chilina gallardoi & Monte Caseros / III & KT820421* & KT820427* \\
\hline Chilina rushii & Gualeguaychú river / III & KT820423* & -- \\
\hline Chilina fluminea & Punta Lara / IV & KT807833*\# & -- \\
\hline Chilina fluminea & Punta Lara / IV & KT807832*\# & -- \\
\hline Chilina fluminea & Punta Lara / IV & KT807831*\# & -- \\
\hline Chilina fluminea & Punta Lara / IV & KT807834*\# & -- \\
\hline Chilina fluminea & Punta Lara / IV & KT820422* & KT820426* \\
\hline Chilina iguazuensis & Iguazú National Park / I & KT807837*\# & -- \\
\hline Chilina iguazuensis & Iguazú National Park / I & KT807838*\# & -- \\
\hline Chilina iguazuensis & Iguazú National Park / I & KT807836*\# & -- \\
\hline Chilina iguazuensis & Iguazú National Park / I & KT807835*\# & -- \\
\hline Chilina megastoma & Iguazú National Park / I & KT807839*\# & -- \\
\hline Chilina sanjuanina & Aguas Negras / VI & KC347574 & -- \\
\hline Chilina mendozana & Uspallata / VI & KC347575 & -- \\
\hline Lymnaea diaphana & & JF909501 & -- \\
\hline
\end{tabular}
611 VI Cuyo.

612

613 
614 Table 5 Pairwise genetic divergence (Kimura two-parameter, \%) among species of Chilina assessed by means of cytochrome $c$

615 oxidase subunit I (COI) gene sequences. GenBank accession numbers are indicated in parentheses.

\begin{tabular}{|c|c|c|c|c|c|c|c|c|c|c|c|c|c|c|}
\hline & & 1 & 2 & 3 & 4 & 5 & 6 & 7 & 8 & 9 & 10 & 11 & 12 & 13 \\
\hline \multicolumn{15}{|c|}{1 C. fluminea (KT807831/33; KT820422) } \\
\hline 2 & C. fluminea (KT807832) & 0.15 & & & & & & & & & & & & \\
\hline 3 & C. fluminea (KT807834) & 0.31 & 0.46 & & & & & & & & & & & \\
\hline 4 & C. rushii (KT820423) & 1.24 & 1.39 & 1.55 & & & & & & & & & & \\
\hline 5 & C. gallardoi (KT820421) & 2.98 & 3.14 & 3.3 & 2.66 & & & & & & & & & \\
\hline 6 & C. santiagoi sp. nov. (KT820418) & 2.97 & 3.13 & 3.29 & 3.14 & 2.66 & & & & & & & & \\
\hline 7 & C. nicolasi sp. nov (KT820419) & 2.97 & 3.13 & 3.29 & 3.14 & 2.34 & 1.24 & & & & & & & \\
\hline & C. luciae sp. nov. (KT820420) & 5.27 & 5.44 & 5.61 & 5.45 & 4.29 & 3.79 & 3.79 & & & & & & \\
\hline & C. iguazuensis (KT807838) & 8.01 & 8.19 & 7.66 & 8.75 & 7.68 & 6.67 & 7.35 & 8.58 & & & & & \\
\hline & C. iguazuensis (KT807833/37) & 7.84 & 8.01 & 7.48 & 8.57 & 7.5 & 6.49 & 7.17 & 8.4 & 0.15 & & & & \\
\hline & C. iguazuensis (KT807836) & 7.49 & 7.67 & 7.14 & 8.22 & 7.16 & 6.48 & 6.83 & 8.05 & 0.46 & 0.31 & & & \\
\hline & C. megastoma (KT807839) & 8.52 & 8.7 & 8.17 & 8.9 & 9.63 & 8.72 & 8.9 & 9.62 & 7.83 & 7.65 & 7.66 & & \\
\hline & C. sanjuanina (KC347575) & 11.8 & 12 & 11.4 & 12 & 11.6 & 11.3 & 11.8 & 12 & 10.7 & 10.5 & 10.1 & 13.8 & \\
\hline & C. mendozana (KC347574) & 10.8 & 11 & 10.5 & 10.3 & 11.4 & 10.7 & 11.2 & 10.7 & 11.2 & 11 & 10.7 & 12.8 & 3.64 \\
\hline
\end{tabular}

616

617 
619 Table 6 Pairwise genetic divergence (Kimura two-parameter, \%) among species of Chilina 620 assessed by means of cytochrome b (Cyt b) gene sequences. GenBank accession numbers are 621 indicated in parentheses.

\begin{tabular}{lllll}
\hline & & 1 & $\mathbf{2}$ & $\mathbf{3}$ \\
\hline 1 & C. fluminea (KT820426) & & & \\
2 & C. santiagoi sp. nov. (KT820424) & 2.91 & & \\
3 & C. luciae sp. nov. (KT820425) & 4.26 & 3.99 & \\
4 & C. gallardoi (KT820427) & 4.00 & 3.46 & 4.82 \\
\hline
\end{tabular}

622

623 
624 Figure 1 Shell measurements used for Chilinidae. TL: total length; LWL: last whorl length; AL: 625 aperture length; TW: total width; AW: aperture width; AP: aperture projection.

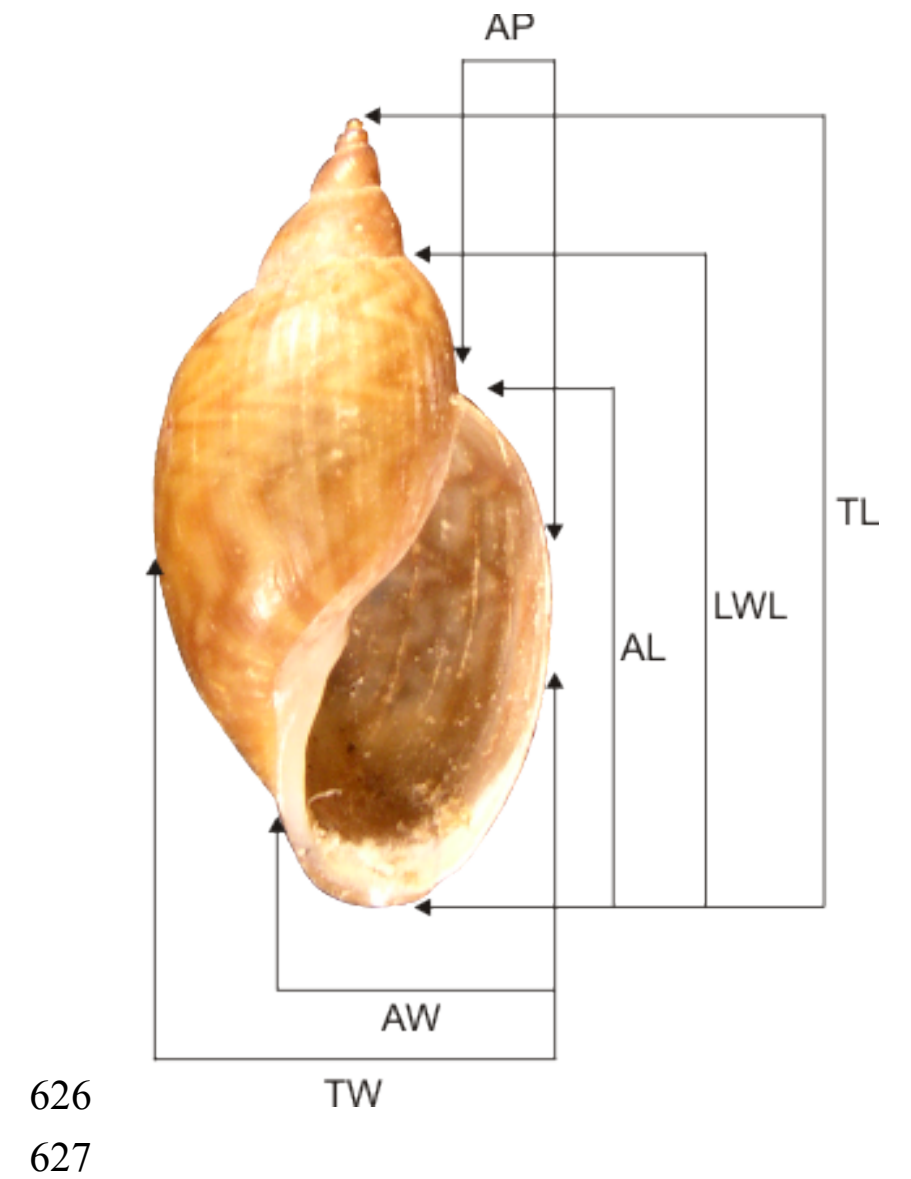


628 Figure 2 Shells of new species (Holotypes). A-C. Chilina nicolasi. D-F. Chilina santiagoi. G-I. 629 Chilina luciae. 


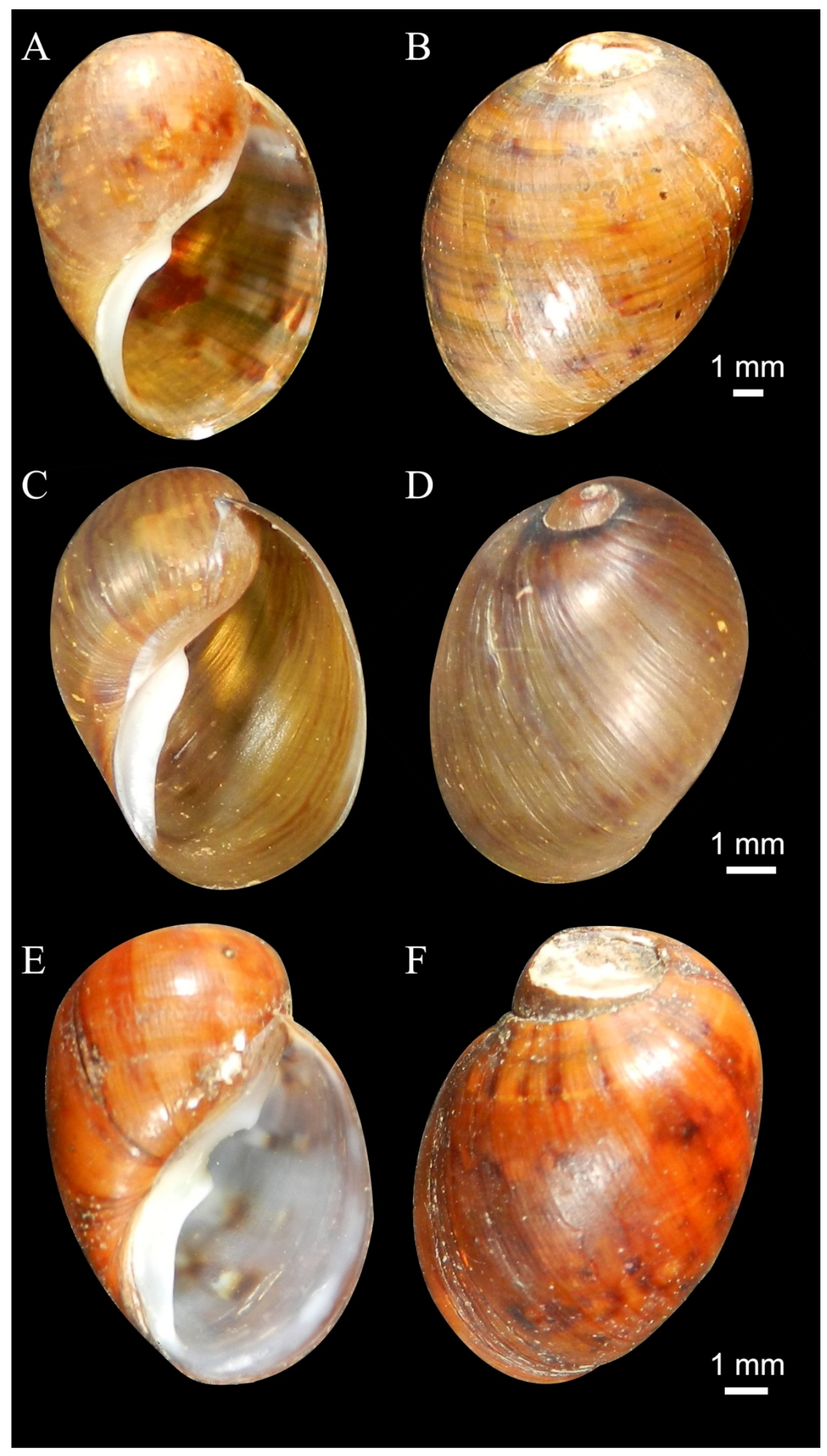


632 Figure 3 Chilina nicolasi sp. nov. A. Diagram of dorsal view of part of the reproductive system.

633 B. Penis inner wall. Abbreviations: ag, albumen gland; bc, bursa copulatrix; bcd, bursa

634 copulatrix duct; pe, penis; pr, prostate; pp, preputium; prm, penis retractor muscle; ps, penis

635 sheath; pu, pustules; sbc, secondary bursa copulatrix; va, vagina; vd, vas deferens. C. Diagram of 636 nervous system. Abbreviations: lc, left cerebral; lpe, left pedal; lp, left parietal; lpl, left pleural;

637 rc, right cerebral; rpe, right pedal; rp, right parietal; rpl, right pleural; so, subesphageal; v, 638 visceral. Scale bar: $1.0 \mathrm{~mm}$.

639 


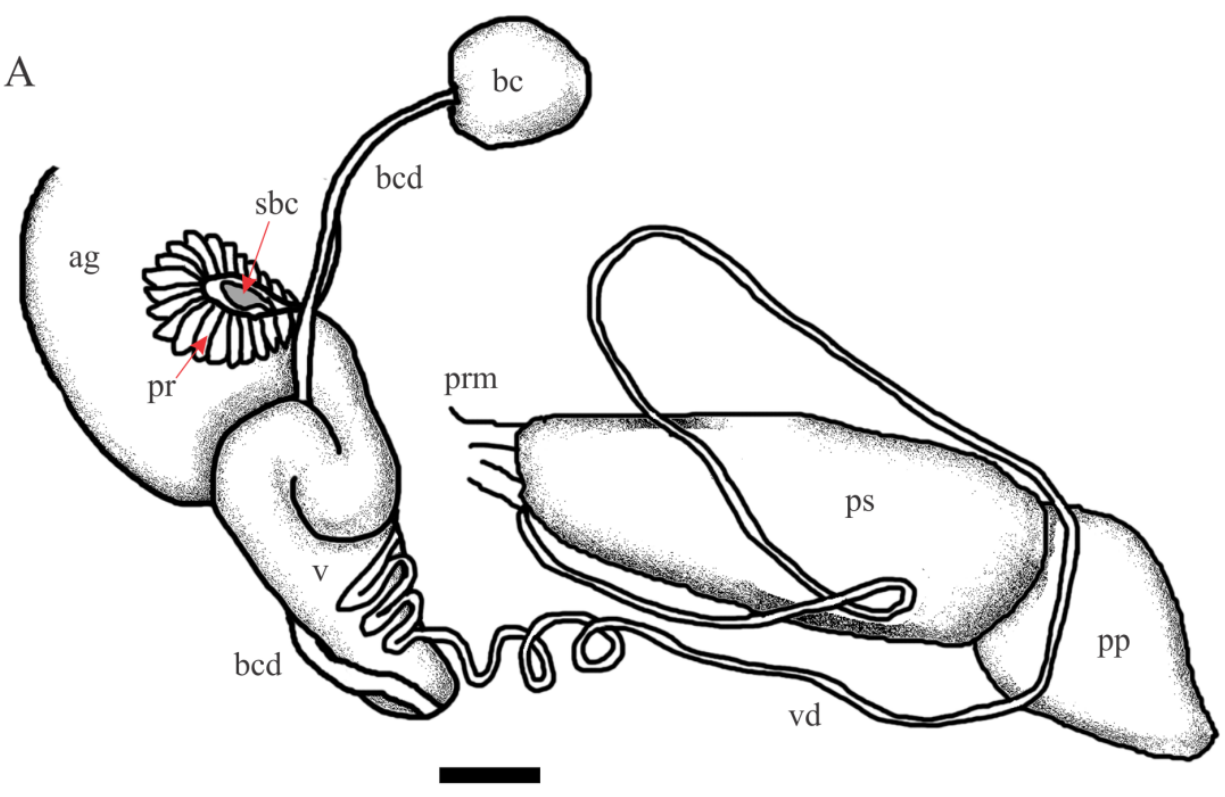

B

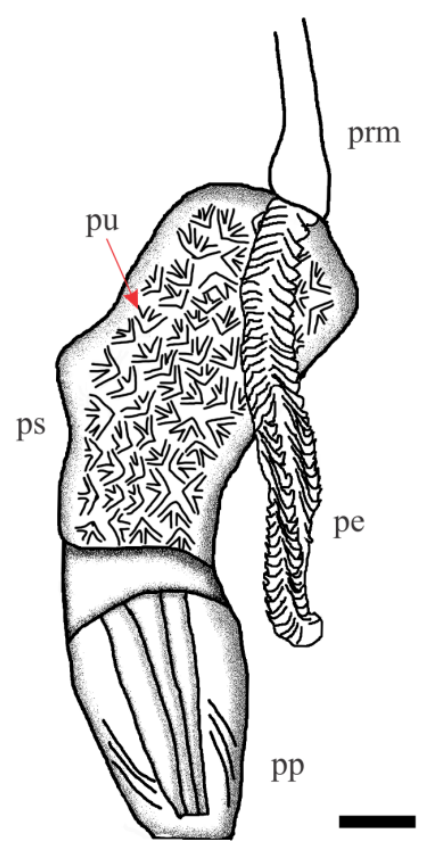

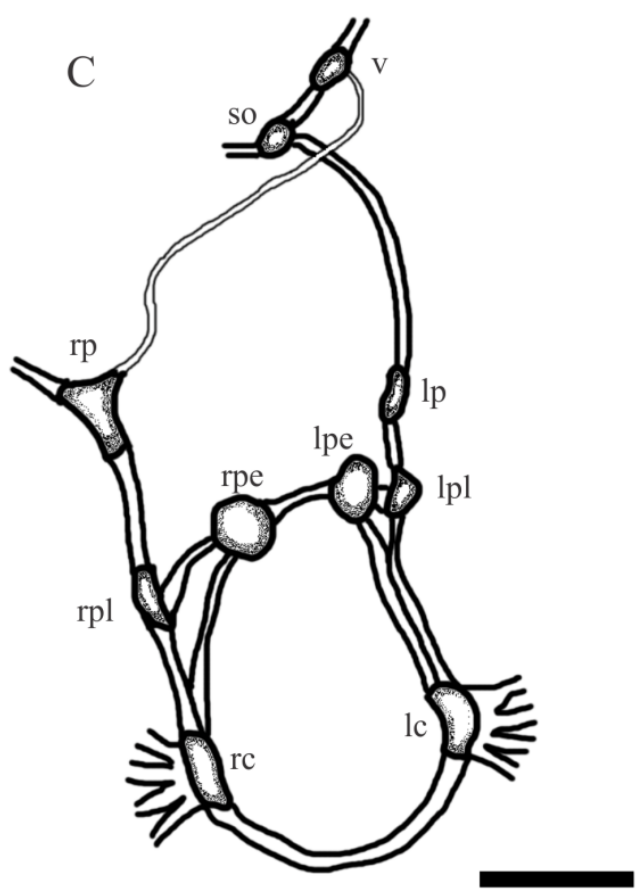

640 
641 Figure 4 Radulae: A-E. Chilina nicolasi sp. nov. from Alba Posse, Misiones province,

642 Argentina. F-H. Chilina santiagoi sp. nov. from Horacio Foerster Falls, Misiones Province,

643 Argentina. I-K. Chilina luciae sp. nov. from Pesiguero Stream, Misiones Province, Argentina. A.

644 General view. B. General view of anterior part. C, F, I. Central tooth and first lateral teeth. D, G,

645 J. Central tooth. E, H, K. Lateral teeth.
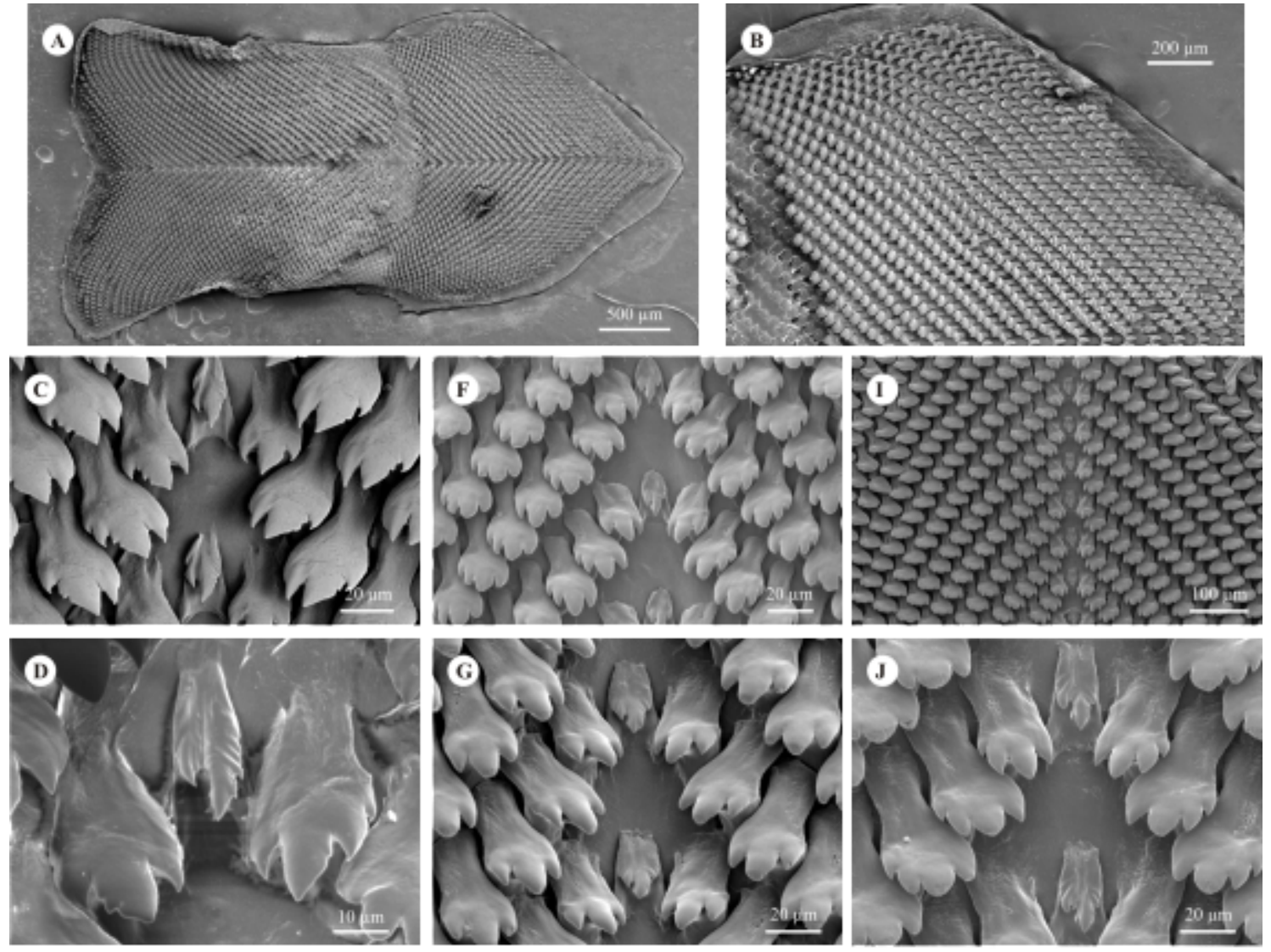

646
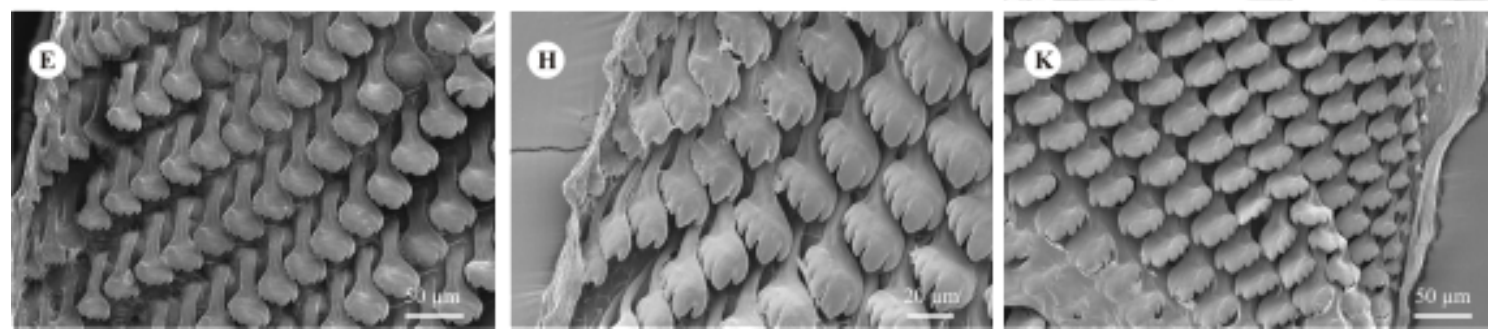

647 
648 Figure 5 A. Malacological provinces of Argentina, I. Misionerean; II. Middle Paraná; III.

649 Uruguay River; IV. Lower Paraná - Río de la Plata; V. Central; VI. Cuyo; VII. Northern

650 Patagonia; VIII. Southern Patagonia. Diagonal pattern: Transitional Zone. B. Species distribution

651 of Chilinidae in the Misiones province, Argentina: green; Misionerean malacological province;

652 light blue: Uruguay River malacological province: $\$$ : Chilina santiagoi sp. nov.; $\star$ : Chilina

653 nicolasi sp. nov.; : Chilina luciae sp. nov.; $\mathbf{\Delta}$ : Chilina megastoma; $\mathbf{\square}:$ Chilina iguazuensis; $\mathbf{\nabla}$ :

654 Chilina gallardoi; $\bullet:$ Chilina rushii; ४ Chilina guaraniana. 


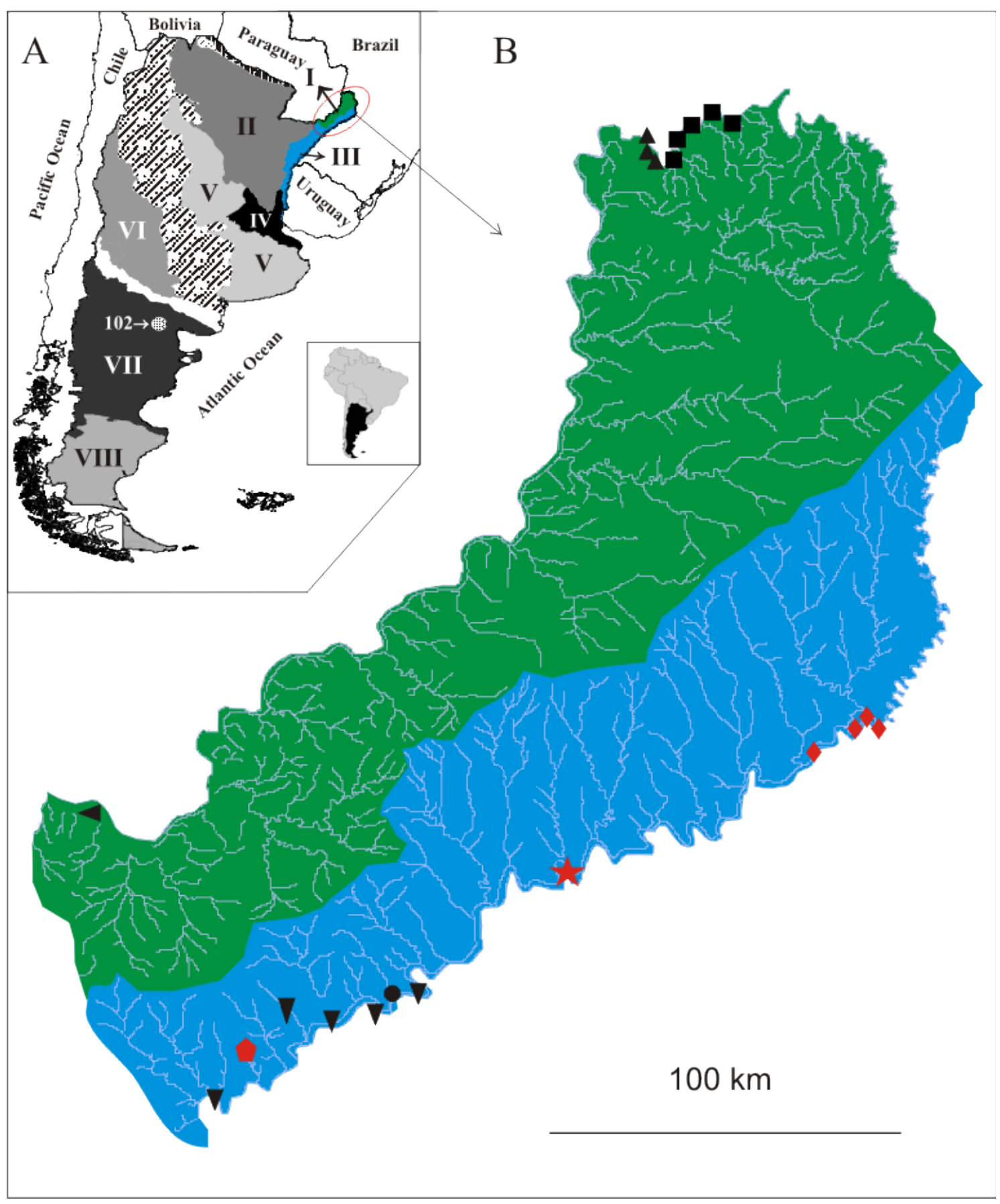

655

656 
657 Figure 6 Chilina santiagoi sp. nov. A. Diagram of dorsal view of part of the reproductive 658 system. B. Penis inner wall. Abbreviations: ag, albumen gland; bc, bursa copulatrix; bcd, bursa 659 copulatrix duct; pe, penis; pr, prostate; pp, preputium; prm, penis retractor muscle; ps, penis 660 sheath; pu, pustules; va, vagina; vd, vas deferens. C. Diagram of nervous system: Abbreviations: 661 lc, left cerebral; lpe, left pedal; lp, left parietal; lpl, left pleural; rc, right cerebral; rpe, right pedal; 662 rp, right parietal; rpl, right pleural; so, subesphageal; v, visceral. Scale bar: $1.0 \mathrm{~mm}$.

663 
A
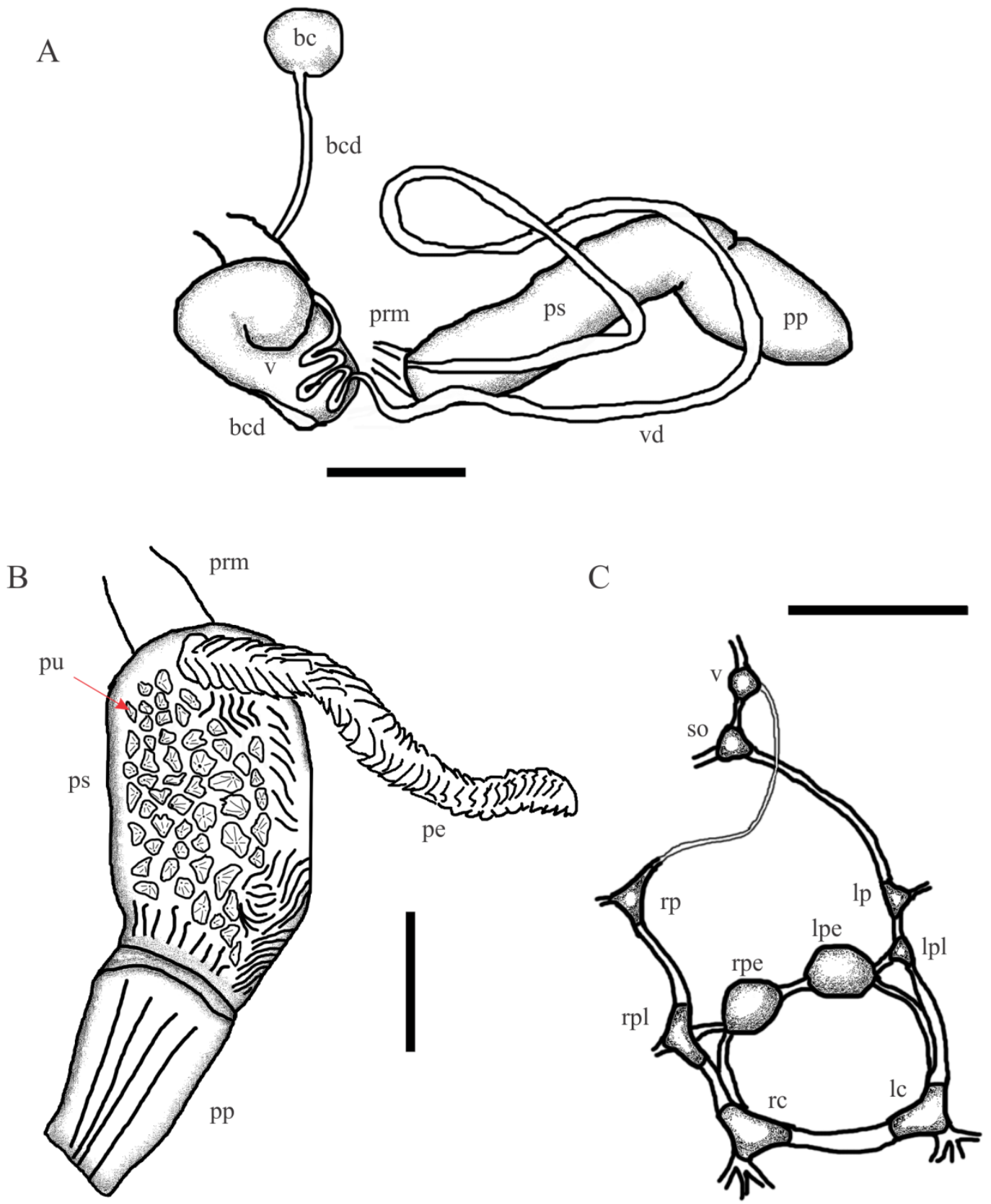
665 Figure 7 Chilina luciae sp. nov. A. Diagram of dorsal view of part of the reproductive system.

666 B. Penis inner wall. Abbreviations: ag, albumen gland; bc, bursa copulatrix; bcd, bursa

667 copulatrix duct; lf: longitudinal folds; pe, penis; pr, prostate; pp, preputium; ps, penis sheath; pu,

668 pustules; sbc, secondary bursa copulatrix; va, vagina; vd vas deferens. C. Diagram of nervous

669 system: Abbreviations: lc, left cerebral; lpe, left pedal; lp, left parietal; lpl, left pleural; rc, right

670 cerebral; rpe, right pedal; rp, right parietal; rpl, right pleural; so, subesphageal; v, visceral. Scale

671 bar: $1.0 \mathrm{~mm}$. 


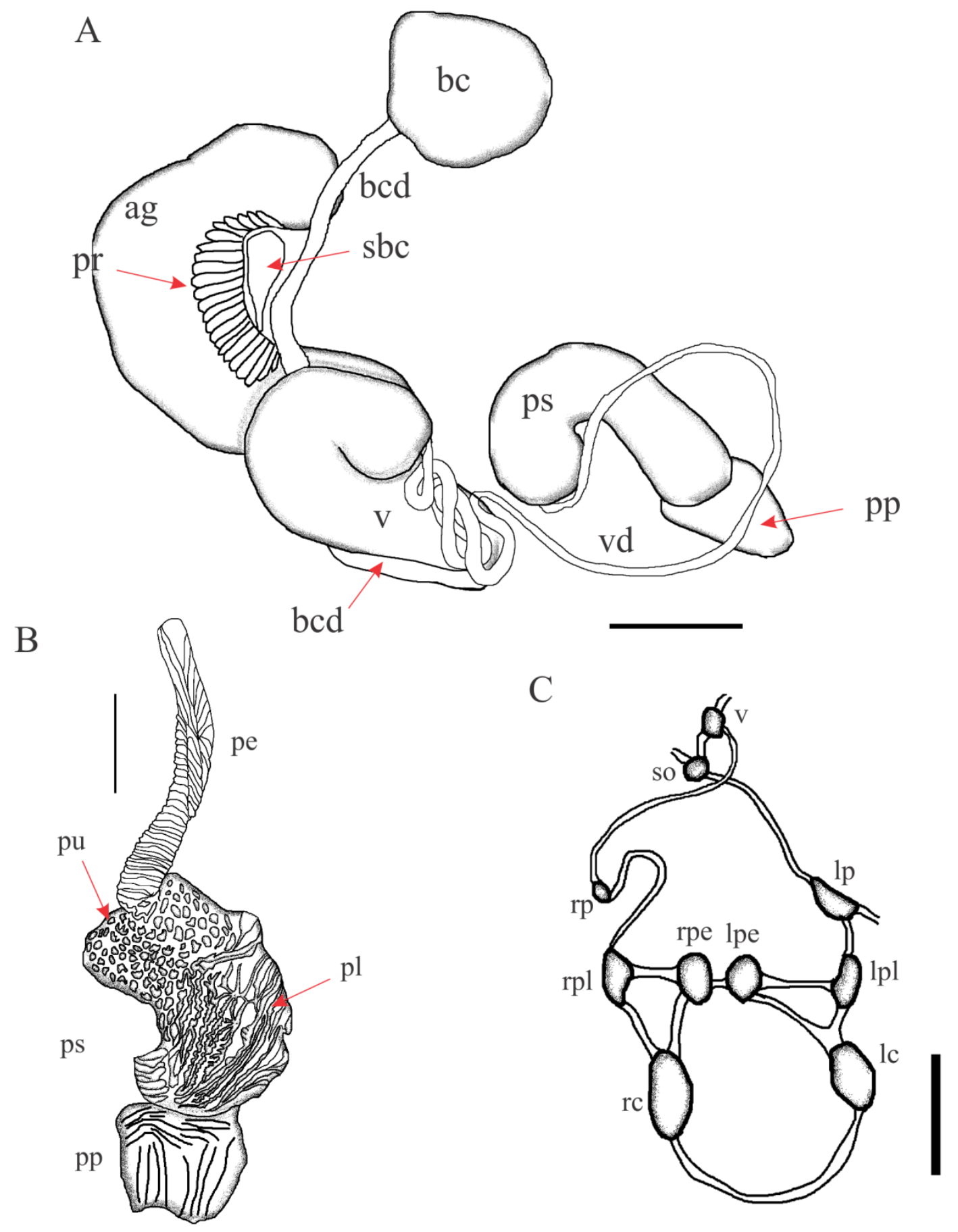

672 
673 Figure 8 Phylogenetic trees of Chilinidae from the Del Plata basin based on a 655-bp fragment 674 of the COI gene. A. Neighbour-joining (NJ) tree. B. Bayesian consensus tree. The support 675 values, bootstrap values (NJ) and posterior probabilities (Bayesian inference), are shown above 676 and below the branches. The trees contains two well supported clades corresponding to the 677 species of Misionerean (green bar) and Uruguay River and Lower Paraná - Río de la Plata (light 678 blue bar) malacological provinces. The numbers within the clades are the corresponding 679 GenBank accession numbers.

A

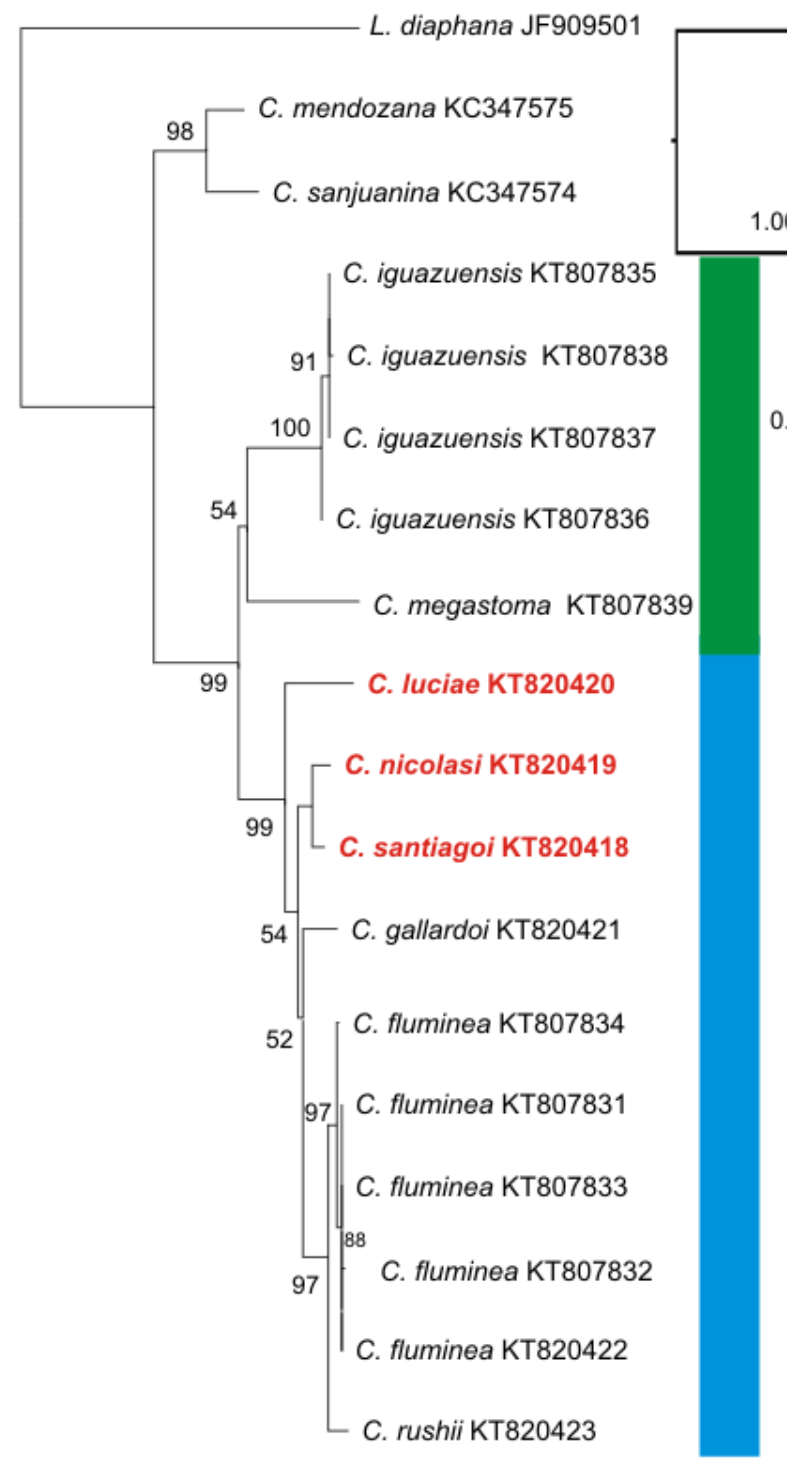

B

L. diaphana JF909501

C. mendozana KC347575

C. sanjuanina $\mathrm{KC} 347574$

C. megastoma KT807839

.97

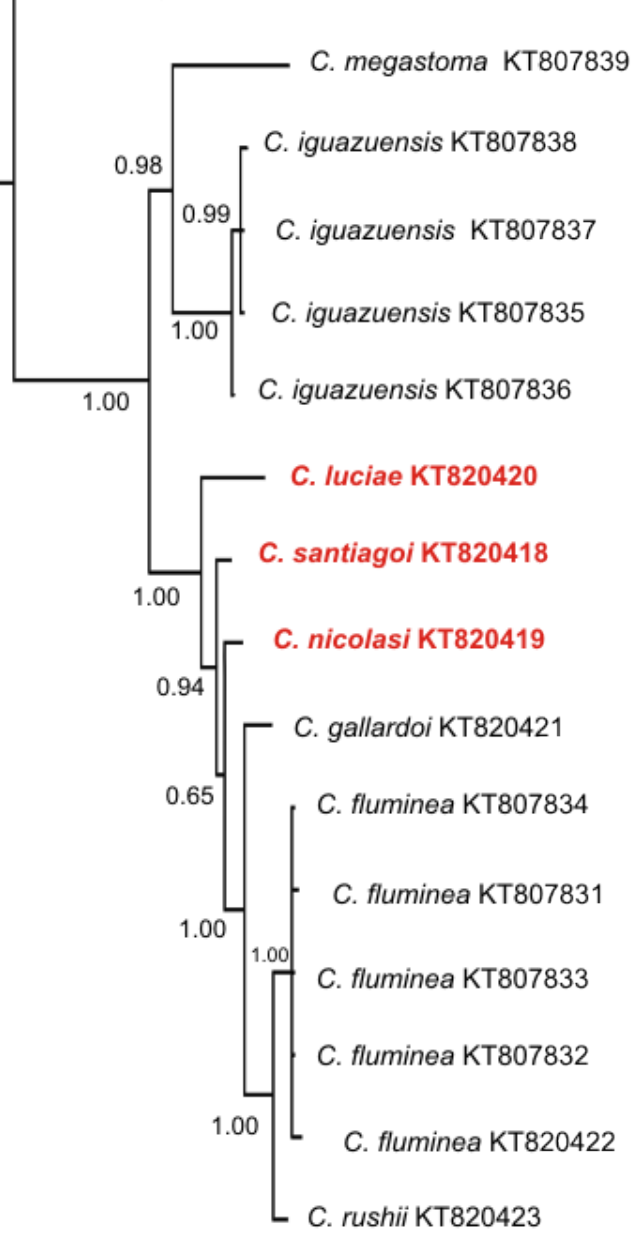

